\title{
Impacts of industrial and entrepreneurial jobs on youth: 5-year experimental evidence on factory job offers and cash grants in Ethiopia
}

\author{
Christopher Blattman Stefan Dercon Simon Franklin*
}

August 2020

\begin{abstract}
We study two interventions for poor and underemployed Ethiopian youth: a $\$ 300$ grant to spur self-employment, and a job offer to an industrial firm. Each one is designed to help overcome a common barrier to employment - financial market imperfections, or matching frictions. We find significant impacts on occupational choice, income, and health in the first year. After five years, however, we see no evidence of long run effects of either intervention. The grant led short-run increases in self-employment, productivity and earnings, but these appear to dissipate over time as recipients exit their businesses. Worrisomely, offers of factory work had no effect on employment or earnings, but led to serious adverse effects on health after one year. Evidence of these effects is gone after five years as well, however. These results point to convergence in most outcomes, and suggest that one-time and one-dimensional interventions may struggle to overcome barriers to wage- or self-employment.
\end{abstract}

JEL codes: J24, O14, F16, J81, O17

Keywords: entrepreneurship, cash transfers, wage labor, factories, employment, poverty, occupational choice, health, field experiment

${ }^{*}$ We thank the participating firms plus the Ethiopian Development Research Institute and Innovations for Poverty Action for field research. For comments we thank Ben Olken and seminar participants. For funding we thank the Private Enterprise Development in Low-Income Countries (PEDL) initiative and the U.K. Department for International Development. Prior rounds were funded by the Aspen ANDE group, the International Growth Center, the Templeton Foundation, and a Vanguard Charitable Trust. Natalie Carlson, Peter Deffebach, Felipe Dizon, Courtney Han, Dawit Kebede, Sana Khan, Benjamin Morse, Richard Peck, Patryk Perkowski, Katherine Rodrigues, Joe St. Clair, Nolawi Taddesse, and Nynne Warring provided research assistance.

Blattman (corresponding author): University of Chicago Harris Public Policy and NBER, blattman@ uchicago.edu; Dercon: Oxford University, Centre for the Study of African Economies, Department of Economics and Blavatnik School of Government, stefan.dercon@qeh.ox.ac.uk; Franklin: Queen Mary University of London, School of Economics, s.franklin@qmul.ac.uk. 


\section{Introduction}

In developing countries, low-skilled youth often spend long periods of time underemployed or not employed at all. Young women often face steeper challenges than men and exhibit lower rates of labour force participation and higher rates of unemployment. This paper assesses whether young people in Ethiopia face barriers to entry into occupations for which they would be otherwise well suited - either from financial market imperfections or matching frictions (Banerjee and Newman, 1993; Pissarides, 2011).

In particular, we created a panel of young, mostly female, low-skilled job-seekers in Ethiopia over a period of five years and used two experiments to analyze whether one-time interventions can overcome impediments to entering two of the most common types of work: (i) low-skill wage work, especially in factories; and (ii) self-employment in petty business and other microenterprises.

Between 2010 and 2013, we identified nearly 1000 people interested in an industrial job at one of five firms. The firms were in different sectors and regions, each one hiring a large batch of workers for a line expansion, sometimes multiple cohorts over time. Most of the eligible applicants were healthy but unemployed women in their early 20 s with no formal work experience. Most had informal experience, however, and were interested and had experience in entrepreneurial work as well as the factory work.

We designed two experimental interventions: a cash grant intended to expand their selfemployment options, and a factory job offer intended to reduce barriers to entry in wage employment. Thus, the job-seekers were assigned to either a start-up grant, the job offer, or a control group. After a baseline survey, we re-interviewed the sample after roughly 1 and 5 years, finding 85-90\%.

The first intervention was a cash grant worth roughly $\$ 300$, equal to about one year's income at prevailing wages. We framed it as a business start-up grant, and it came with a few days of training and consulting on microenterprises. We repeatedly stressed to participants, however, that the grant was unconditional. We designed this treatment arm to address the fact that, qualitatively, many of the subjects described a desire to start a small enterprise, but did not have the capital or access to credit to do so. ${ }^{1}$ This is a commonplace friction among youth in developing countries; they may have opportunities in "entrepreneurial" selfemployment, in agriculture or petty trades, but lack the initial capital required to start such small businesses. They may also face uncertainty about their own ability to run an enterprise and not be able to take the risk of experimenting with this kind of work.

Many studies have provided evidence of short-run returns to cash or in-kind grants across

\footnotetext{
${ }^{1}$ See Banerjee and Duflo (2011) and Blattman and Ralston (2015).
} 
a range of contexts. Much of this evidence comes from studies with populations of existing entrepreneurs and farmers. ${ }^{2}$ Several studies find high average returns to capital among populations at large in these largely traditional economies. ${ }^{3}$ Questions remain, however, including whether this will hold in more modern economies (especially industrializing contexts), and whether short-run returns to grants will be sustained in the longer run. This paper brings new evidence to both questions.

Theory suggests that, unless people are hampered by extreme constraints and frictions, over time individuals without access to grants should be able to earn and save enough to make the same microenterprise investments, and eventually catch-up. On the other hand, we would expect sustained long-run effects in the presence of either (a) increasing returns to capital as suggested by theories of poverty traps or (b) severe savings and credit constraints that prevent the control group from ever getting the capital to begin their own businesses. Long-run evidence is sorely lacking.

In the second experiment, we worked with the industrial firms to randomize offers to entry-level jobs. We observed queues of young people, mostly women, applying for industrial jobs around Ethiopia, most of whom were turned away because of insufficient new openings. ${ }^{4}$ Following months of qualitative observation and interviews around dozens of factories, we hypothesized that these industrial jobs were widely desired but scarce. One reason is that a school of thought and a large body of observational evidence suggest that formal firms offer more stable employment or pay premium wages, especially large, foreign-owned, or exporting firms. ${ }^{5}$

After one year, we found no evidence of more stable employment or wage premiums from factory jobs. However, recipients of the offer still worked $40 \%$ more hours in factory

\footnotetext{
${ }^{2}$ For existing entrepreneurs see Mel, McKenzie, and Woodruff (2012) and Fafchamps et al. (2014) and Hussam, Rigol, and Roth (2017). For farmers see (Beaman et al., 2014). Some studies find no sustained impact of grants (Fiala, 2018; Blattman, Jamison, and Sheridan, 2017; Karlan, Osei, et al., 2014).

${ }^{3}$ In Uganda, grants plus training led to large income gains after 18 months (Blattman, Annan, et al., 2016). Unconditional cash to Kenyan villagers led to increases in assets but no consumption impacts after 3 years (Haushofer and Shapiro (2016) and Haushofer and Shapiro (2018)). Cash transfers in Mexico led to higher income after 1-2 years (Gertler, Martinez, and Rubio, 2012; Bianchi and Bobba, 2013). Across 7 countries, programs that gave livestock with basic training and some cash show increases on the incomes and consumption of the poorest rural households after 4 years (Banerjee, Karlan, and Zinman, 2015; Bandiera et al., 2013; Bandiera et al., 2017).

${ }^{4}$ Ethiopia has been a growing export hub in horticulture, textiles, and leather. As countries like Ethiopia enter the early stages of industrialization, the number of low-skill industrial job opportunities have grown.

${ }^{5}$ Theoretically, there are several reasons why industrial work would pay a wage premium compared to informal work. Firms may pay efficiency wages or there may also be institutional and legislative sources, such as minimum wages, labor codes, or union bargaining (Katz et al., 1989; Akerlof and Yellen, 1986; Card, 1996). If so, the result is a dual or segmented labor market, in which those gaining industrial jobs earn rents while informal workers queue for those jobs (Lewis, 1954; Harris and Todaro, 1970; Fields, 1975). Empirical contributions include Bernard, Robertson, and Schott (2010), Verhoogen (2008), Söderbom and Teal (2004), and El Badaoui, Strobl, and Walsh (2008).
} 
jobs in the two weeks of the 1-year endline. This paper investigates longer term effects of this shift in occupational choice. One reason this is important is that industrial jobs could still set young workers on a job ladder that leads to scarce skills, better jobs, and higher wages over time, especially young women. ${ }^{6}$ There are two reasons. One is that the job offer encouraged experimentation with a new sector and new matches. By allowing 'good' types to get a foot in the door, we may see their wages rise with tenure and from climbing up the job ladder (even if this is a minority of those offered the jobs). After all, hiring among firms in developing countries is prone to considerable frictions and information asymmetries, which may prevent firms from selecting the workers who are most likely to flourish in careers in these occupations. ${ }^{7}$ Second, most of our sample was unemployed for at least a month before they entered our sample, either due to adverse shocks or because they are entering the labor market for the first time or after a spell of unemployment. A range of research in more developed labor markets suggests that market conditions and opportunities for such people matter a great deal for long term labor market prospects (Arulampalam, Gregg, and Gregory, 2001; Kroft, Lange, and Notowidigdo, 2013).

After 5 years, however, generally speaking we do not find support for either of our hypotheses. We see no evidence that large start-up grants lead to sustained income changes, nor that entry-level industrial jobs affect long-run employment outcomes. Specifically, we find three main results.

First, the positive impacts of the cash disappear. In the 1-year study, we saw evidence that the start-up grant dramatically raised productivity and earnings, mostly in microenterprises (Blattman and Dercon, 2018). ${ }^{8}$ After 5 years, however, we see no evidence of the microenterprises and productivity gains. The treatment effect estimates on income and employment are in fact slightly negative and not statistically significant. While there is always uncertainty surrounding any "null" effect, our estimates generally rule out an increase in income or employment of more than 0.1 standard deviations. ${ }^{9}$

\footnotetext{
${ }^{6}$ Women are commonly employed in low-skill firms, and there is observational evidence that working in textile factories or other export manufacturers raises women's status in the household, their quality of life, and the health of children (Kabeer, 2002; Hewett and Amin, 2000; Atkin, 2009; Getahun and Villanger, 2016).

${ }^{7}$ Abebe, Caria, Fafchamps, et al. (2018), Bassi and Nansamba (2017), Abel, Burger, and Piraino (2017), and Abebe, Caria, and Ortiz-Ospina (2017) Young people and women in particular in Ethiopia may also face uncertainty about their own proclivities and abilities for industrial work, be unaware of health and other risks, or face other search and matching frictions. Because so many low-skilled people apply to the still small number of industrial firms, even well-matched individuals may never get the opportunity to enter into these occupations.

${ }^{8}$ We find nothing in the 1-year data to predict the almost complete dissipation of these impacts: the vast majority of the grant money was invested by the recipients, into the types of microenterprises that are no less profitable than others, on average.

${ }^{9} \mathrm{~A}$ transition to marriage and child-rearing does not appear to be driving the results: only $35 \%$ of the
} 
This suggests that equilibrium labor market outcomes are not affected by injections of liquidity. This is consistent with concurrent evidence, most of which principally comes from rural and traditional economies. Balboni et al. (2020) provide evidence for the existence of long-run poverty traps among very poor rural farmers in Bangladesh. On the other hand, Blattman, Fiala, and Martinez (2019) find no long-run effects of group-based cash transfers to existing micro-entrepreneurs in relatively remote parts of post-conflict Uganda. There are also almost no long-run evaluations involving youth who did not start out as microentrepreneurs, to the best of our knowledge. In the case of cash grants targeted to young women age 18 to 19 in especially poor neighbourhoods of Nairobi, Brudevold-Newman et al. (2017) find that earnings effects dissipate after two years.

Second, we find that the industrial jobs had only temporary adverse effects on health. Our 1-year results showed that those who took the factory job were more likely to report substantial health problems a year after the job offer, even though the average employee quit after a few weeks or months. It is extremely important to understand if such health problems are chronic. The short-term evidence raised the concern that people experimenting with factory work might not understand the risks, and that industrial work could lead to large, chronic, and unanticipated health problems. With so many low-income countries industrializing, this is a first order concern for human welfare.

We returned with a battery of expanded measures, and pre-specified health as our second primary outcome after incomes. We see no evidence of long term adverse effects from the industrial work. Those assigned to the industrial job offer have 3 months more cumulative experience in factories than the control group, and neither reduced-form treatment effects nor an instrumental variables approach suggest that this added factory work reduced health in the long run. The treatment effect estimate is close to zero, and the coefficient on an index of physical health is statistically significantly lower than after 1 year. After 5 years, we can rule out a 0.15 standard deviation decline in health. This implies, at least in this instance, the adverse health effects seem to have been temporary.

Third, after 5 years we do not see any evidence of people climbing the industrial job ladder or of wages rising with tenure. Again, we can rule out improvements greater than 0.1 standard deviations. Only one in six people remain in factory work, even among those randomly offered the job. From our data and qualitative work, it seems that people in all three arms used factory jobs as a safety net to smooth income temporarily until other less rigid and less risky work could be found. Altogether, these results are consistent with the simple alternative hypothesis that industrial jobs are not higher-quality and "rare" jobs, but women are married and have children at the 5 -year endline. 
rather are average to low quality jobs where labor markets function normally. ${ }^{10}$

In the end, a main takeaway from this experiment is that two of the interventions that some schools of thought think should have large lasting effects on poverty simply do not have these impacts, at least in this setting and with young women. ${ }^{11}$ One interpretation is that one-off interventions and nudges addressing a single or small number of market failures may not be lasting. Powerful forces may push individuals back towards equilibrium outcomes irrespective of interventions. This is largely speculative, but if more interventions in more places fail to find long run effects of initially-successful poverty or employment interventions, it may challenge the widespread marginalist view of poverty alleviation. This could push interventions to be more multifaceted addressing multiple barriers at once, and perhaps addressing constraints at the local or macro level as well.

\section{Setting}

Ethiopia is the second most populous nation in Africa after Nigeria, and also one of the poorest. 27 percent live under $\$ 2$ a day in purchasing power parity (PPP) terms, and agriculture employs 85 percent of the workforce. Like many African countries, the underdeveloped private sector has offered few formal sector jobs. Youth unemployment and underemployment are high. Most young people are engaged in informal wage work or self-employment.

At the same time, Ethiopia is also one of the fastest growing economies in the region, with GDP growth of roughly $10 \%$ per year from 2006-16. In particular, Ethiopia has become a growing export hub in horticulture, textiles, and leather. Although the economy has been moving in fits and starts through the early stages of of industrialization, Ethiopia has been touted as one of China's successors in light manufacturing (The Economist, 2014). The country has several advantages from a manufacturer's point of view: low wages, a politically stable and foreign investment-friendly regime, a domestic market of 94 million people, and proximity to Europe.

Over the last two decades, there has been a transformation in Ethiopia's urban labor markets. They have become more flexible, with rising importance of private sector work, no

\footnotetext{
${ }^{10}$ Recent studies conducted in Ethiopia find positive short-run impacts of randomized factory jobs on both employment and earnings (Abebe, Buehren, and Goldstein, 2020). Another, by Sandra Kristine Halvorsen, has not yet appeared in working paper form, to the best of our knowledge. These studies work with different firms but also different applicant populations to ours. Studying heterogeneous treatments effects using overlapping support in the distribution of characteristics of applicants across the three studies would be an interesting avenue for future work.

${ }^{11}$ By schools of thought, we refer to our earlier summary of: (1) the literature on cash transfers that highlights financial market constraints and increasing returns in production as a correctable market failure; and (2) the theoretical and empirical literatures on the gains from employment in the export and manufacturing sectors.
} 
obvious skill premiums between the private and public sector, and lower (but still considerable) urban unemployment. In all the firms in our study, and in general across the private sector, employers can set wages without any legal restriction or reference to union deals. The governing labor law makes it also relatively straightforward to fire an employee.

In the years prior to our study, 2000-08, national income and industrial output both grew about 10 percent per year, with the number of medium and large manufacturers doubling in number (CSA, 2011). The beginning of the study period was first a boom time followed by a mild slow down. Even so, during this period new foreign firms were entering the market and starting small plants, and some domestic firms were continuing to invest and expand. Growth picked up later in the study period, and again Ethiopia is now one of the fastest growing economies in the region.

\section{Experimental sample, procedures, and data}

\subsection{Experimental sample}

Our sample of young people comes from job applicants to 5 industrial firms, in 5 different sectors and 4 regions of the country, both urban and rural. Two firms hired more than one cohort over the study period, 2010-13, for a total of eight cohorts. Table 2 describes the firms and cohorts. Three firms engaged in light manufacturing (textiles and garments, shoes, and beverages) and two in commercial agriculture (flowers and vegetables). Four were export-oriented. Only one was foreign-owned.

Eligible job applicants were recruited and screened in the firms' standard fashion, described below. Only these screened applicants were eligible for one of the two treatments: an industrial job offer or the start-up grant package. Table 1 reports baseline characteristics of these screened applicants, from self-reported surveys. ${ }^{12} 80$ percent were women. The average applicant was 22 and had completed grade 9. Most were unmarried.

One concern might be that this sample was not interested in or predisposed to entrepreneurial work and self-employment. If anything, however, the opposite was the case. Qualitatively, in interviews, most expressed an equal or greater interest in running home enterprises compared to factory work. Many reported that they were constrained by a lack of starting capital. This motivated the start-up grant treatment arm, discussed below. Indeed, most of the sample were already active "micro-entrepreneurs", though they were often

\footnotetext{
${ }^{12}$ Applicants completed a 90-minute baseline survey plus 45 minutes of interactive games, with real money, to measure time and risk preferences, and cognitive abilities such as executive function. An Ethiopian enumerator delivered surveys and the games verbally in the local language. The games remunerated the respondent with roughly a half days wages.
} 
Table 1: Covariate balance at baseline

\begin{tabular}{|c|c|c|c|c|c|}
\hline \multirow[b]{2}{*}{$\begin{array}{l}\text { Baseline covariates } \\
(\mathrm{N} \text {-control }=358, \mathrm{~N} \text {-job }=304, \mathrm{~N} \text {-grant }=285)\end{array}$} & \multirow{2}{*}{$\begin{array}{c}\text { Control } \\
\text { mean } \\
(1)\end{array}$} & \multicolumn{2}{|c|}{ Job-Control } & \multicolumn{2}{|c|}{ Grant-Control } \\
\hline & & $\begin{array}{c}\text { Diff } \\
(2)\end{array}$ & $\begin{array}{c}\text { p-value } \\
(3)\end{array}$ & $\begin{array}{l}\text { Diff } \\
(4)\end{array}$ & $\begin{array}{c}\mathrm{p} \text {-value } \\
(5)\end{array}$ \\
\hline Age & 22.02 & -0.12 & 0.68 & -0.14 & 0.63 \\
\hline Female & 0.80 & -0.00 & & 0.00 & \\
\hline Unmarried & 0.81 & $-0.06^{*}$ & 0.07 & -0.04 & 0.25 \\
\hline Muslim & 0.05 & -0.00 & 0.90 & 0.00 & 0.98 \\
\hline Household Size & 4.35 & -0.13 & 0.45 & -0.14 & 0.45 \\
\hline Household head & 0.23 & 0.04 & 0.25 & -0.00 & 0.96 \\
\hline Proportion of household dependents & 0.43 & -0.00 & 0.98 & -0.00 & 0.96 \\
\hline Total years of education and training & 9.31 & -0.20 & 0.34 & -0.02 & 0.92 \\
\hline Executive function, z-score & 0.11 & $-0.18^{* *}$ & 0.01 & $-0.13^{*}$ & 0.08 \\
\hline Weekly cash earnings, 2010 Birr & 9.57 & 0.59 & 0.81 & -1.44 & 0.57 \\
\hline Durable assets, z-score & 0.09 & -0.11 & 0.13 & $-0.13^{*}$ & 0.06 \\
\hline Ever worked in a large firm & 0.27 & -0.03 & 0.43 & 0.05 & 0.18 \\
\hline Hrs work/wk, past two weeks & 7.52 & -0.09 & 0.94 & -0.36 & 0.80 \\
\hline No work in past 4 weeks & 0.68 & 0.01 & 0.86 & -0.01 & 0.76 \\
\hline Highest - lowest earnings, past month & 181.38 & $39.44^{*}$ & 0.05 & 15.84 & 0.33 \\
\hline Could borrow 3000 birr & 0.31 & 0.04 & 0.27 & -0.00 & 0.98 \\
\hline Ability to do activities of daily life $(0-15)$ & 14.32 & 0.09 & 0.40 & 0.10 & 0.31 \\
\hline Disability: Great difficulty at more than 1 activities & 0.01 & -0.01 & 0.26 & -0.00 & 0.77 \\
\hline Risk aversion, z-score & -0.01 & -0.05 & 0.55 & 0.10 & 0.20 \\
\hline Future orientation, z-score & 0.10 & -0.06 & 0.45 & -0.03 & 0.73 \\
\hline Locus of control index & -0.04 & 0.04 & 0.62 & 0.13 & 0.12 \\
\hline Self esteem index, s-score & -0.05 & 0.03 & 0.75 & 0.06 & 0.42 \\
\hline Family relations index, z-score & -0.05 & -0.02 & 0.77 & 0.07 & 0.35 \\
\hline Friends and nieghbors relations index & -0.01 & -0.05 & 0.49 & 0.00 & 0.95 \\
\hline Change in subjective well being, past yr. & 0.22 & $0.20^{* *}$ & 0.03 & 0.09 & 0.33 \\
\hline Symptoms of depression, z-score & -0.02 & 0.02 & 0.82 & 0.01 & 0.94 \\
\hline Symptoms of anxiety, z-score & -0.04 & 0.05 & 0.50 & -0.01 & 0.92 \\
\hline Agressive or hostile behaviors, z-score & 0.04 & -0.06 & 0.44 & -0.13 & 0.11 \\
\hline Conscientiousness index, z-score & -0.00 & 0.01 & 0.89 & 0.04 & 0.65 \\
\hline Years experience, private firm & 0.34 & $0.17^{*}$ & 0.08 & $0.22^{* *}$ & 0.02 \\
\hline Years experience, workshop & 0.01 & 0.00 & 0.73 & 0.01 & 0.27 \\
\hline Years experience, government/NGO & 0.08 & -0.02 & 0.67 & 0.02 & 0.73 \\
\hline Probability of a better job, next month & 0.68 & -0.01 & 0.47 & -0.01 & 0.72 \\
\hline Probability of full-time work, next month & 0.55 & 0.01 & 0.74 & 0.03 & 0.17 \\
\hline
\end{tabular}

${ }^{*}$ indicates $p<.1,{ }^{* *}$ indicates $p<.05$, and ${ }^{* * *}$ indicates $p<.01$. Regression estimates are calculated with district and cohort fixed effects. Standard errors are clustered at the level of the respondent due to having two observations per person. 


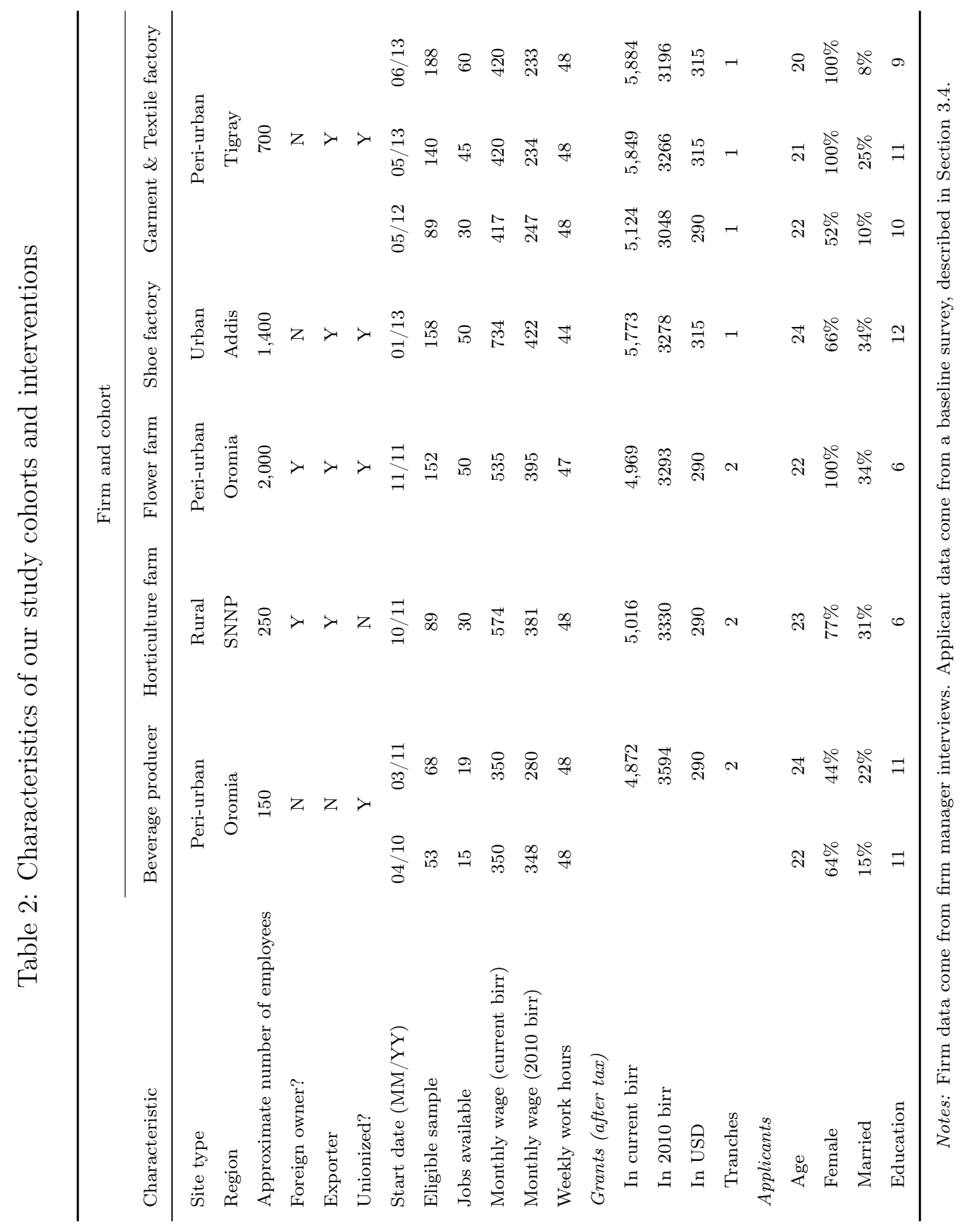


under-employed. As we see from Table 1, the average sample member had 7.5 hours of work per week, typically a portfolio of activities such as farming, casual labor, or petty business. They had earned little cash in the previous month.

Finally, most of the sample had little experience in or information about industrial work. Only 27 percent had worked in a large, formal firm before, and only 19 percent in a factory. Based on our qualitative interviews, most applicants had only a hazy idea of the type and difficulty of the work in advance, and often only learned the salary being offered at the time of hiring.

\section{$3.2 \quad$ Interventions}

\subsection{1 "Start-up" grant and training}

The core of the start-up treatment was an unconditional cash grant of nearly 5000 Birr, or roughly $\$ 300$. (see Table 2). ${ }^{13}$ We chose the $\$ 300$ amount based on our qualitative assessment of the costs required to set up a small part-time enterprise. While we framed the cash grant as a business start-up fund, throughout the intervention we made clear that it was nonetheless an unconditional grant and grantees were free to use it as they saw fit - savings, consumption, or investment.

To encourage and enable business start-up, however, grantees initially received five days of business training and planning. ${ }^{14}$ Professional skills trainers led classes of about 20, and each person also received individual mentoring during those five days. ${ }^{15}$ Subjects had to complete at least three days of the training to receive the grant.

\subsubsection{Industrial job offer}

The jobs involved working on production lines where the workers bottled water, picked and packed produce and flowers, cut fabric, or sewed shoes. They could involve heavy machinery or simple tools.

\footnotetext{
${ }^{13}$ The grant amount varied slightly from cohort to cohort because of inflation, currency devaluation, and tax issues. For cohorts 2 to 4, a for-profit firm ran the intervention and was required to withhold tax on the grants. To minimize the tax burden the cash was disbursed in two tranches several weeks apart. We used a for-profit firm because we could not find a non-profit organization willing to disburse cash without conditions at low cost. For cohorts 5 to 8, we ran the intervention through a parastatal research organization to avoid the tax burden. The amount of the grant was increased to maintain the rough purchasing power and disbursed in a single tranche to reduce implementation costs.

${ }^{14}$ Total implementation cost of training and grant was roughly $\$ 450$ per person including the grant, training, and local program administration.

${ }^{15}$ Cohorts 2 and 3 also received a follow-up visit by the trainer after three months for additional advice. Grantees did not see this service as helpful, and given the cost it was discontinued after cohort 3 .
} 
In terms of eligibility, the positions required no previous work experience. Applicants had to be healthy and able-bodied. All firms also had a minimum education requirement - grade 6 in the two rural horticulture firms, and grade 8 or 10 in the more urban manufacturing ones. Most firms had separate jobs for men and women, and depending on the position they were hiring for, they would specify a gender.

The positions required 45 to 50 hours per week over 5 or 6 days. At the time of the baseline surveys, the jobs typically paid a wage of $\$ 1$ to $\$ 1.50$ per day at 2010 market exchange rates (where $\$ 1=13.5$ birr in 2010). Some firms offered non-wage benefits such as on-site health care and bus transport.

The workplaces were professional and well-maintained, and firms never coerced employees. Nonetheless, health risks were common, especially: air quality (dust particles or chemical fumes); discomfort and fainting from standing or lack of breaks or water; and safety hazards such as wet floors, sharp instruments, and so forth. In interviews, workers who used cleaning solvents, pesticides, dyes and glues sometimes reported fainting from inhalation.

Most firms were unionized, but these were generally worker associations that mediated disputes but did not engage in collective bargaining. Occasionally, however, we did observe short strikes or walkouts in response to salary delays.

\subsection{Recruitment}

\subsubsection{Firm recruitment and selection}

We approached roughly 300 firms, about half of all private industrial firms in Ethiopia with 50 or more employees. ${ }^{16}$ We contacted them by phone or walk-in. To be eligible for the study, a firm had to be in manufacturing or commercial farming, expect to hire a batch of at least 15 low-skill, full-time workers, and be willing to randomly assign job offers among screened applicants.

The limiting factor was whether a firm had imminent large expansion plans. Only a handful had plans to open a entire new production line and hire a large batch of workers at once. ${ }^{17}$ Firms with more modest expansion plans were a poor fit for the study, as they

\footnotetext{
${ }^{16}$ We identified these firms through applications for investment certificates, public business listings, industry associations, and personal contacts.

${ }^{17}$ One reason is that sector growth was slowing in this period. 2010 to 2012 in Ethiopia was a period of moderate government financial repression and pre-election uncertainty. Despite a growing economy and a boom in some sectors, such as construction, many of the existing firms we approached were temporarily holding off on growth plans. Other common sources of delay included difficulty in obtaining licenses, foreign exchange, importing equipment, and obtaining parts. At least two other firms intended to participate, but suffered prolonged delays and did not open their new line during the study period. Also, some sector growth was coming from new firms, often foreign-owned, who were reluctant to participate because their start-up was already complicated enough.
} 
planned to hire people piecemeal, to accommodate more gradual growth and cope with regular attrition.

Randomization was seldom an issue, and more than three-quarters of the firms we approached were open to the study. ${ }^{18}$ While one might expect that firms want to select the best workers, low-skill entry-level positions were often filled without a substantive interview process. In most of the firms we approached, entry-level hiring was ad hoc in the sense firms filling low-skill positions on a first-come, first-hire manner, with little or no interview process.

What are these five study firms a case of? Our data suggest the jobs are similar to other labor-intensive, low-skill, entry-level positions in the large textile, garment, footwear, beverage, and commercial farming sectors, and thus different from positions in higher-skill and heavier or more capital-intensive manufacturing. Compared to a representative sample of industrial firms in 2014 in the capital Addis Ababa, our five firms had higher revenues, lower profits, two to three times as many production employees, and lower-skilled employees. ${ }^{19}$

It is reasonable to worry that firms willing to randomize employment were poorly managed or had unusual turnover. While possible, qualitatively we saw little difference between our firms and the others we approached. On the contrary, all were expanding employment, suggesting they had more credit and higher returns to investment than others.

\subsubsection{Sample recruitment and selection}

We followed each firms' normal procedures for hiring batches of new employees to staff new production lines. The firms advertised jobs through a posting on the front gate, word of mouth, and local job boards. ${ }^{20}$ Applicants were instructed to gather on a specific day. Firm

\footnotetext{
${ }^{18}$ They typically expressed interest in participation in the study for several reasons: curiosity in the answer; the opportunity to bring some structure to relatively unstructured hiring processes; and an interest in learning more about their applicant pool and the other opportunities available to their employees.

${ }^{19}$ Given the low-skill nature of the work and the entry-level positions, starting salaries were lower than the manufacturing average - at roughly the 25th percentile of manufacturers in the capital. Since most of our firms are outside the capital, the purchasing power of their wages is greater, probably putting them between the 25 th and 50th percentile in terms of wages. Moreover, comparing wages to the distribution quoted in the $2009 / 10$ census of manufacturing firms suggest that they were not at all uncommon for the specific sectors involved. The modal workers in the census earned between 400-600 birr in 2010 prices, with the second most common interval 200-400 birr, jointly making up 40 percent of the workforce in manufacturing in general and more than 60 percent in textiles or footwear (CSA, 2011). The wages of the workers in our sample fall in these ranges.

${ }^{20}$ In order to ensure sufficient applicants, we only made one change to standard procedures: we assisted the firm in posting more notices within a wider radius than usual (usually no more than a few kilometers). Since the firm typically drew employees from this radius, we expected this to generate an applicant pool very similar to the usual one. It is possible, however, that the experimental pool of applicants is further outside the family/friend network, and lives slightly further from the factory, than would otherwise have been the case. That said, most applicants live within a few miles of the firm, and so are extremely local by
} 
managers would then screen written or verbal applications, typically based on job-specific gender, education, and health requirements. Across all 8 cohorts, between 75 and 95 percent of applicants passed these criteria and thus entered the study sample. We do not have data on ineligible applicants.

A research team from Innovations for Poverty Action (IPA) and the Ethiopian Development Research Institute (EDRI) then debriefed eligible applicants on the study, the start-up arm arm, and the survey and randomization procedures. Nearly all agreed to enter the study, completed a baseline survey, and entered the lottery.

Following randomization, the firm posted the names of people receiving the job offer at the factory site and the IPA/EDRI research team contacted all those assigned to two treatment arms. Job offers began within a few days and the start-up training and grants within a few weeks.

We gave each firm a list of unsuccessful applicants and asked the firm not to hire them for at least 1-2 months. In practice, however, the firms kept poor records and within a few days or weeks of the randomization could have hired control group members.

\subsection{Randomization and balance}

We randomized by cohort, stratified by gender, using a uniform random variable generator. 304 were assigned to the job offer, 285 to the start-up grant arm, and 358 to the control arm.

The sample is somewhat imbalanced across the treatment arms at baseline. Table 1 reports tests of randomization balance, where we regress each covariate on treatment indicators plus randomization block (cohort-gender) fixed effects. Appendix Table A.I reports the same statistics on the subsample who were interviewed after 5 years, from which we draw similar conclusions. Of the 34 covariates across two treatments, 8 of the 68 mean differences (12 percent) have $p<.1$. Those assigned to jobs are less likely to be married and have slightly lower executive functions and education compared to the control group. Those assigned to the entrepreneurship program have lower assets and more firm experience. A test of joint significance of all covariates has a p-value of 0.04 for the job offer and 0.01 for the entrepreneurship program. To minimize bias, we control for baseline covariates when estimating treatment effects.

any measure. (The firms, who were reluctant to hire people who lived far away, reported that they did not think the distance would make a material difference, since all live nearby.) 


\subsection{Outcomes}

\subsubsection{1- and 5-year endline data}

We conducted follow-up surveys roughly 1 and 5 years after assignment to the two treatments. At each of these two endlines, we attempted to reach each respondent twice, roughly 2-3 months apart, to measure our main outcomes twice. We did so to improve statistical precision with highly-variable outcomes such as earnings or consumption (McKenzie, 2012). ${ }^{21}$

During site visits to several dozen factories and commercial farms, we conducted informal interviews with workers and managers. At each study firm we systematically interviewed managers at every level from senior management to line managers. Research assistants also interviewed 138 workers and microenterprise owners, both in and out of the sample. They also conducted 60 exit interviews by phone with sample members who quit the study firms.

\subsubsection{Attrition}

Our sample frequently moved between survey waves. We were able to track down $88 \%$ after 1 year and $84.3 \%$ after five. ${ }^{22}$ Appendix Table A.II reports the correlates of attrition after 5 years, from a simple regression of an attrition indicator on baseline covariates.

After 1 year, all treatment arms were roughly as likely to be found. After 5 years, those assigned to the job offer were no more likely to be found after five years than the control group. But those assigned to the start-up arm were roughly 5 percentage points more likely to be found and interviewed. Controlling for baseline covariates, this difference is not statistically significant, but it is potentially substantively important. Thus, below, we will consider the robustness of our estimates to alternative attrition scenarios and sensitivity analysis.

\subsubsection{Primary outcomes and dealing with multiple outcomes}

Based on the 1-year findings, our pre-analysis plan for the 5-year endline pre-specified two primary outcomes of interest: income and physical health. As secondary outcomes we specified an interest in occupational choice and quality. We designated all other outcomes as exploratory. ${ }^{23}$

\footnotetext{
${ }^{21}$ For the 1-year survey, we also attempted to interview the household head once, since the sample member may have been a dependent and unaware of household labor allocations, wealth, and attitudes. At the 5-year survey, given that the sample is considerably older, we did not interview household heads.

${ }^{22}$ For discussion of the rates and pattern of attrition for the 1-year endline survey, see Blattman and Dercon (2018).

${ }^{23}$ See https : //www. socialscienceregistry.org/trials/2198
} 
We divided outcomes into primary and secondary to minimize the number of hypotheses tested. To further minimize comparisons, we assembled our various measures into a family index of income and a family index of health. Our tables report treatment effects on the components of these indexes as well, but those comparisons should be regarded as exploratory. ${ }^{24}$

\subsection{Estimation}

To estimate program impacts on outcome $Y$, we calculate the intent-to-treat (ITT) estimate of the job offer and start-up arms via OLS:

$$
Y_{i r j}=\alpha_{j}+\gamma_{r}+\theta_{J} J_{o b_{i j}}+\theta_{E} \text { Startup }_{i j}+\beta \mathbf{X}_{i j}+\epsilon_{i j}
$$

where Job and Startup are indicators for random assignment to the treatment arms. To account for observed baseline imbalance and endline attrition, we control for the baseline covariates, $X$, listed in Table 1 , as well as gender-cohort fixed effects, $\alpha_{j}$. At each endline, we surveyed respondents in two different rounds $r$, collecting the same outcome two times. Each round enters the regression as a separate observation, and we cluster standard errors by individual and include round fixed effects, $\gamma_{r=2}$. Unless otherwise stated, all results in the paper show average effects across both rounds pooled together.

We estimate $\theta_{E}$ and $\theta_{J}$ for each endline (1-year and 5-year) separately using Equation 1. In order to test for the equality of coefficients across endlines we stack our two endlines to estimate:

$$
Y_{i r j t}=\alpha_{j t}+\gamma_{r}+\theta_{J, t} J o b_{i j}+\theta_{E, t} \operatorname{Startup}_{i j}+\beta_{t} \mathbf{X}_{i j}+\epsilon_{i j t}
$$

where we allow the coefficients on all independent variables to vary with time. We then conduct simple t-tests for the equality of $\theta_{J, t=1}$ and $\theta_{J, t=5}$, and $\theta_{E, t=1}$ and $\theta_{E, t=5}$, respectively.

Note that all outcomes are self-reported, and each treatment arm was aware of their assignment and the existence of other arms. Thus, there is the potential for self-reported outcomes to vary with treatment status. As with most low-income countries, there are no administrative data on earnings. And as with most countries, there are no systematic and available administrative data on health or informal earnings.

\footnotetext{
${ }^{24}$ We rely on two primary indexes ("Income and consumption z-score" and "Physical health z-score") to make the main argument of the paper. As a result we do not adjust out p-values for multiple comparisons across outcomes presented in the paper.
} 


\section{Results}

\subsection{Economic impacts}

Income and employment levels Table 3 reports 1- and 5-year ITT estimates for measures of income and employment levels. ${ }^{25}$ Our primary economic outcome is income. We have two measures of income, pre-specified, that we combine into an income family index. One is the sum of weekly cash earnings across 22 different occupations. Earnings are seasonal and do not reflect home production, so we also consider a measure of non-durable consumption in the previous 4 weeks via an abbreviated consumption module of 82 items. $^{26}$

In the start-up grant arm, we see a striking short-run divergence followed by convergence within 5 years. The income and consumption z-score increases 0.15 standard deviations after one year (including a one third increase in reported earnings and a more than $10 \%$ increase in consumption), but there is virtually no income effect after 5 years. The point estimate is -0.039 and, with a standard error of 0.068 , treatment effects above 0.09 standard deviations are outside the $95 \%$ confidence interval.

This temporary income effect from the grant appears to be driven mainly by increased hours of work, almost all through the channel of self-employment in retail trades. We see little difference in earnings per hour reported worked. This increase in employment also disappeared after 5 years. Again the coefficient is negative and impacts greater than 0.09 standard deviations lie outside the $95 \%$ confidence interval.

Notably, we are able to reject the test for equality of coefficients across endlines for our grant treatment, at least on our main (pre-specified) outcomes of interest for which we did see significant treatment effects in year 1 . These results are reported as p-values in Columns 7 and 8 , in the first and second rows of Table 3. In other words, the effects at the 5-year endline are significantly smaller than those found after 1 year.

We see no evidence of an effect of a factory job offer on income or total hours of work after 1 or 5 years. After five years, again increases in income of 0.09 standard deviations or more are outside of the $95 \%$ confident interval.

\footnotetext{
${ }^{25}$ Table 6 consider robustness to various models and scenarios.

${ }^{26}$ See Beegle et al. (2012) for this approach. This abbreviated measure likely understates total consumption by excluding durable asset use and less common purchases. Note that we also pre-specified a third measure of income, an index of almost two dozen durable assets. Due to a survey programming error, however, these durables data were mistakenly not collected in the 5-year endline.
} 
Table 3: Impacts on income and employment

\begin{tabular}{|c|c|c|c|c|c|c|c|c|}
\hline \multirow[b]{3}{*}{ Outcome } & \multicolumn{3}{|c|}{ 1-year Endline } & \multicolumn{3}{|c|}{ 5-year Endline } & \multirow{2}{*}{\multicolumn{2}{|c|}{$\begin{array}{c}\text { Cross-year difference } \\
\text { p-value }\end{array}$}} \\
\hline & \multirow{2}{*}{$\begin{array}{c}\text { Control } \\
\text { mean } \\
(1)\end{array}$} & \multicolumn{2}{|c|}{ ITT Estimate } & \multirow{2}{*}{$\begin{array}{c}\text { Control } \\
\text { mean } \\
(4)\end{array}$} & \multicolumn{2}{|c|}{ ITT Estimate } & & \\
\hline & & $\begin{array}{l}\text { Job } \\
(2)\end{array}$ & $\begin{array}{c}\text { Grant } \\
(3)\end{array}$ & & $\begin{array}{l}\text { Job } \\
(5)\end{array}$ & $\begin{array}{c}\text { Grant } \\
(6)\end{array}$ & $\begin{array}{l}\text { Job } \\
(7)\end{array}$ & $\begin{array}{c}\text { Grant } \\
(8)\end{array}$ \\
\hline Income and consumption, z-score & -0.005 & $\begin{array}{c}0.014 \\
{[0.052]}\end{array}$ & $\begin{array}{c}0.150^{* *} \\
{[0.059]}\end{array}$ & 0.008 & $\begin{array}{l}-0.045 \\
{[0.067]}\end{array}$ & $\begin{array}{l}-0.041 \\
{[0.069]}\end{array}$ & 0.449 & 0.019 \\
\hline Weekly earnings, 2010 Birr & 34.227 & $\begin{array}{l}3.049 \\
{[4.487]}\end{array}$ & $\begin{array}{c}12.005^{* *} \\
{[5.474]}\end{array}$ & 34.970 & $\begin{array}{l}-3.964 \\
{[5.619]}\end{array}$ & $\begin{array}{l}-1.715 \\
{[6.008]}\end{array}$ & 0.316 & 0.071 \\
\hline Earnings per hour, 2010 Birr & 1.562 & $\begin{array}{c}0.074 \\
{[0.269]}\end{array}$ & $\begin{array}{c}0.119 \\
{[0.269]}\end{array}$ & 1.446 & $\begin{array}{l}-0.088 \\
{[0.371]}\end{array}$ & $\begin{array}{c}0.231 \\
{[0.351]}\end{array}$ & 0.723 & 0.797 \\
\hline SD of weekly earnings & 58.150 & $\begin{array}{c}6.256 \\
{[7.685]}\end{array}$ & $\begin{array}{c}4.285 \\
{[8.131]}\end{array}$ & 56.523 & $\begin{array}{c}1.427 \\
{[8.966]}\end{array}$ & $\begin{array}{c}3.833 \\
{[9.945]}\end{array}$ & 0.681 & 0.971 \\
\hline Household nondurable consumption, 2010 birr & 665.049 & $\begin{array}{c}20.548 \\
{[34.719]}\end{array}$ & $\begin{array}{l}76.837^{* *} \\
{[35.560]}\end{array}$ & $1,745.385$ & $\begin{array}{l}-30.133 \\
{[93.510]}\end{array}$ & $\begin{array}{l}-54.871 \\
{[89.547]}\end{array}$ & 0.601 & 0.157 \\
\hline Employment and occupational choice, z-score & -0.038 & $\begin{array}{c}0.079 \\
{[0.074]}\end{array}$ & $\begin{array}{c}0.042 \\
{[0.076]}\end{array}$ & 0.076 & $\begin{array}{l}-0.082 \\
{[0.079]}\end{array}$ & $\begin{array}{l}-0.079 \\
{[0.079]}\end{array}$ & 0.130 & 0.256 \\
\hline Hours work/week, past 2 weeks & 26.394 & $\begin{array}{c}0.997 \\
{[1.898]}\end{array}$ & $\begin{array}{l}3.506^{*} \\
{[1.896]}\end{array}$ & 26.685 & $\begin{array}{l}-1.952 \\
{[2.037]}\end{array}$ & $\begin{array}{l}-1.874 \\
{[2.038]}\end{array}$ & 0.271 & 0.043 \\
\hline Factory labor & 7.463 & $\begin{array}{c}3.017^{* *} \\
{[1.383]}\end{array}$ & $\begin{array}{c}-4.104^{* * *} \\
{[1.171]}\end{array}$ & 6.144 & $\begin{array}{c}0.579 \\
{[1.425]}\end{array}$ & $\begin{array}{c}-3.517^{* * *} \\
{[1.221]}\end{array}$ & 0.173 & 0.692 \\
\hline Farm wage labor & 3.074 & $\begin{array}{l}1.817^{* *} \\
{[0.916]}\end{array}$ & $\begin{array}{c}-1.480^{* *} \\
{[0.745]}\end{array}$ & 0.441 & $\begin{array}{l}0.825^{*} \\
{[0.430]}\end{array}$ & $\begin{array}{c}0.143 \\
{[0.351]}\end{array}$ & 0.285 & 0.040 \\
\hline Smallhoder farming & 0.821 & $\begin{array}{l}-0.258 \\
{[0.323]}\end{array}$ & $\begin{array}{c}1.480^{* * *} \\
{[0.399]}\end{array}$ & 0.219 & $\begin{array}{l}-0.002 \\
{[0.116]}\end{array}$ & $\begin{array}{c}0.130 \\
{[0.143]}\end{array}$ & 0.461 & 0.002 \\
\hline Petty business & 4.037 & $\begin{array}{l}-0.878 \\
{[0.980]}\end{array}$ & $\begin{array}{c}5.381^{* * * *} \\
{[1.382]}\end{array}$ & 5.989 & $\begin{array}{l}-1.981 \\
{[1.318]}\end{array}$ & $\begin{array}{c}-0.621 \\
{[1.293]}\end{array}$ & 0.498 & 0.001 \\
\hline Skilled trades & 1.592 & $\begin{array}{l}-0.736 \\
{[0.450]}\end{array}$ & $\begin{array}{l}-0.576 \\
{[0.484]}\end{array}$ & 3.140 & $\begin{array}{c}-1.414^{* *} \\
{[0.637]}\end{array}$ & $\begin{array}{l}-1.413^{*} \\
{[0.780]}\end{array}$ & 0.344 & 0.296 \\
\hline Casual nonfarm labor & 2.180 & $\begin{array}{l}-0.954^{*} \\
{[0.569]}\end{array}$ & $\begin{array}{c}0.746 \\
{[0.772]}\end{array}$ & 0.814 & $\begin{array}{c}0.612 \\
{[0.467]}\end{array}$ & $\begin{array}{c}0.866 \\
{[0.546]}\end{array}$ & 0.036 & 0.896 \\
\hline Low-skill salaried labor & 4.187 & $\begin{array}{c}0.064 \\
{[1.097]}\end{array}$ & $\begin{array}{l}-0.412 \\
{[0.958]}\end{array}$ & 3.548 & $\begin{array}{l}-0.220 \\
{[0.892]}\end{array}$ & $\begin{array}{c}0.079 \\
{[0.925]}\end{array}$ & 0.831 & 0.696 \\
\hline Hrs Medium-skill salaried labor & 1.209 & $\begin{array}{l}-0.415 \\
{[0.420]}\end{array}$ & $\begin{array}{c}1.604^{* * *} \\
{[0.591]}\end{array}$ & 3.287 & $\begin{array}{c}1.055 \\
{[0.865]}\end{array}$ & $\begin{array}{c}3.258^{* * *} \\
{[0.978]}\end{array}$ & 0.106 & 0.097 \\
\hline Other work & 2.268 & $\begin{array}{l}-0.085 \\
{[0.694]}\end{array}$ & $\begin{array}{c}0.489 \\
{[0.738]}\end{array}$ & 2.262 & $\begin{array}{l}-0.851 \\
{[0.574]}\end{array}$ & $\begin{array}{l}-0.746 \\
{[0.593]}\end{array}$ & 0.362 & 0.156 \\
\hline No work in past two weeks & 0.343 & $\begin{array}{l}-0.013 \\
{[0.033]}\end{array}$ & $\begin{array}{c}-0.082^{* *} \\
{[0.032]}\end{array}$ & 0.409 & $\begin{array}{l}-0.002 \\
{[0.039]}\end{array}$ & $\begin{array}{l}-0.037 \\
{[0.038]}\end{array}$ & 0.813 & 0.341 \\
\hline SD of hours/week & 16.444 & $\begin{array}{l}-1.342 \\
{[1.345]}\end{array}$ & $\begin{array}{l}3.808^{* *} \\
{[1.479]}\end{array}$ & 11.864 & $\begin{array}{c}1.456 \\
{[1.516]}\end{array}$ & $\begin{array}{c}2.584 \\
{[1.594]}\end{array}$ & 0.163 & 0.576 \\
\hline Had migrated at 1-year follow up or 5-year follow up & & & & 0.070 & $\begin{array}{l}-0.013 \\
{[0.018]}\end{array}$ & $\begin{array}{c}0.013 \\
{[0.017]}\end{array}$ & 0.470 & 0.441 \\
\hline Had migrated at endline & 0.048 & $\begin{array}{c}0.020 \\
{[0.019]}\end{array}$ & $\begin{array}{c}0.030 \\
{[0.019]}\end{array}$ & 0.067 & -0.000 & -0.000 & 0.285 & 0.115 \\
\hline
\end{tabular}

${ }^{*}$ indicates $p<.1,{ }^{* *}$ indicates $p<.05$, and ${ }^{* * *}$ indicates $p<.01$. Each row represents one regression with $\mathrm{N}=2,974$ across pooled rounds of data collection. Regression estimates are calculated with district and cohort fixed effects Standard errors are clustered at the level of the respondent due to having two observations per person. All observations are weighted by the inverse of their sampling probability and the inverse of their predicted probability of attrition using a Leave-One-Out logistic predictive method. Control means are also calculated using these weights. In the last two columns we report t-tests for the equivalence of the main experimental coefficients across the 1-year and 5-year endlines. For example in Column (8), row (1) reports the p-value for the test that coefficients in Columns (3) and (6) are equal. 
Figure 1: Progression of income and hours worked across time by treatment status. ITT effects are added to control means.

(a) Mean income (all profits and wages) in past week across time for all cohorts

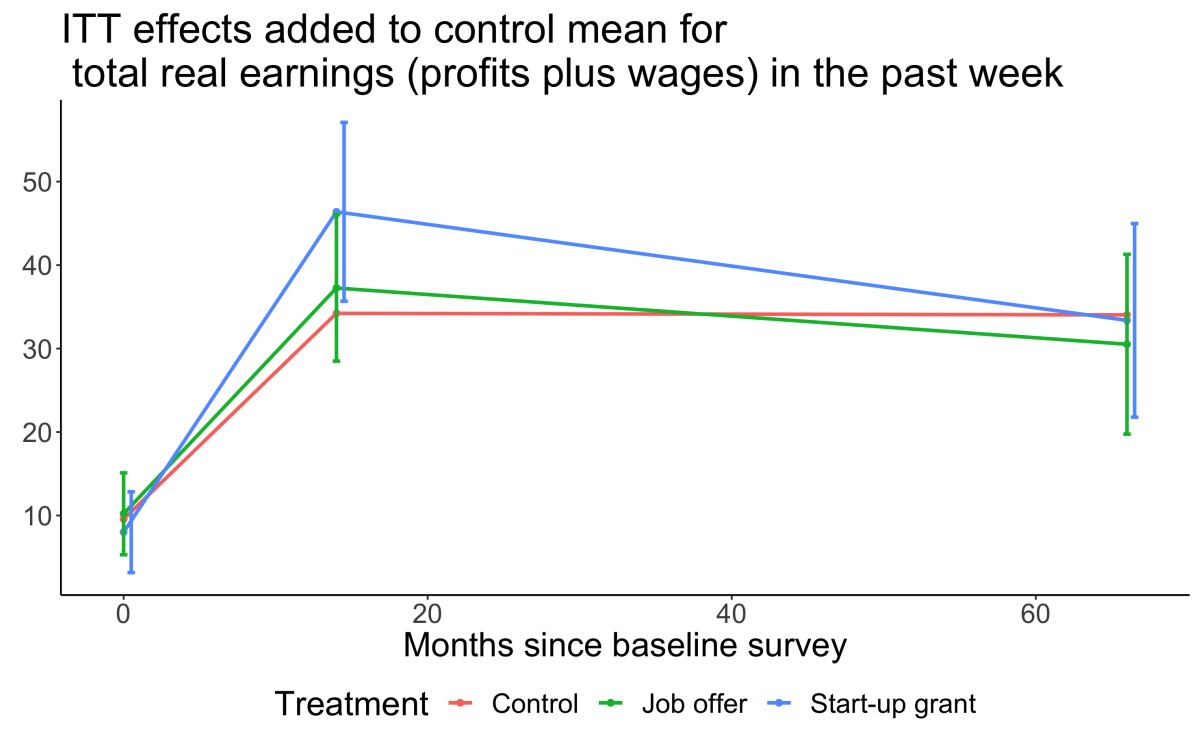

(b) Mean hours worked across time for all cohorts

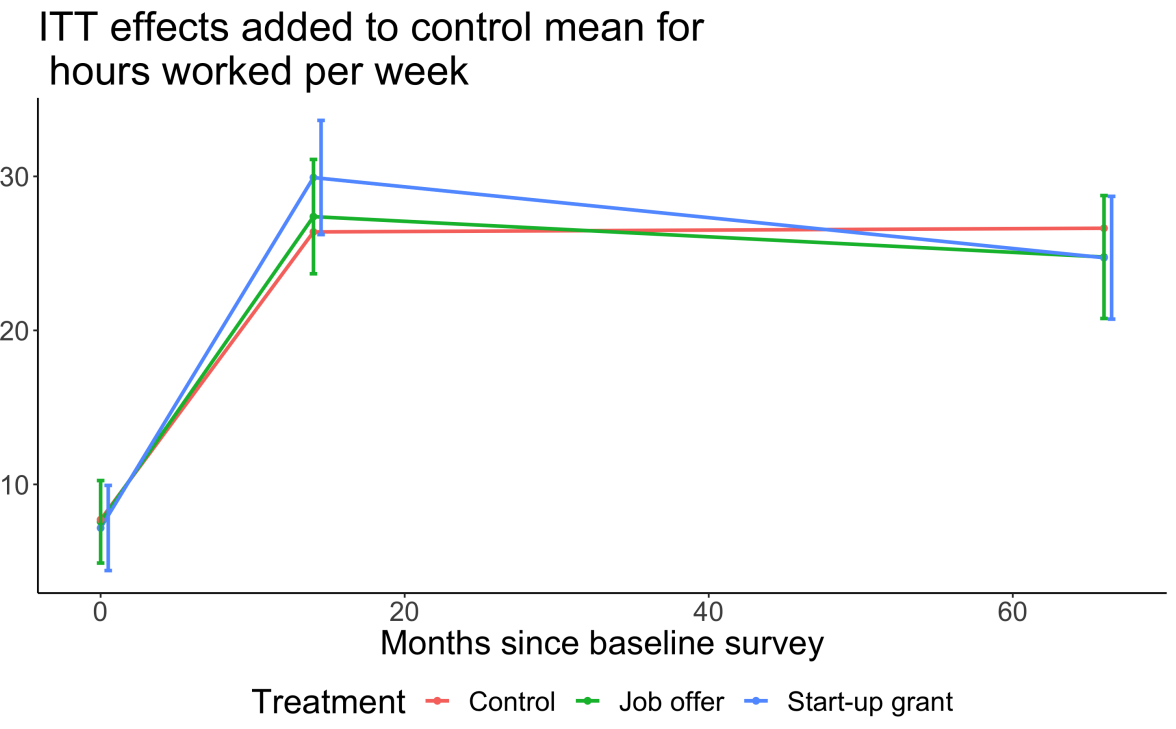

Figures $1 \mathrm{a}$ and $1 \mathrm{~b}$ above plot the main results from Table 3 relative to the baseline means, with all results deflated to 2010 Birr. Both incomes and hours of employment rose steeply in the first year. They stagnated or fell, however, in the subsequent 4 years. The jump in weekly earnings and employment in all three groups in the first year suggests that people self-selected into the sample of job applicants because they were new labor market entrants (the average age of our sample was less 21 at baseline) or had suffered a shock. Employment 
outcomes for the grant group seem fall back down to control group levels, rather than the control group catching up.

Unemployment and occupational choice Figure 2 looks at employment and occupational choice on the extensive margin (pre-specified as secondary outcomes of interest). The probability of being employed fell slightly between the 1 and 5 -year endline. One reason is that a few young women exited the labour force. Others who are unemployed report looking for employment. This may be only partly due to marriage and fertility; only $37 \%$ of women in our sample were married at the second endline and 35\% have children (rates are slightly lower for men). Table A.III in the Appendix shows that neither treatments had any effect on fertility rates.

Examining trends in the control group gives insight to the life-cycle effects of occupational choice in our sample. While slightly more individuals entered self employment between the 1 and 5-year surveys, this increase in employment was counteracted by exit from factory and non-factory wage jobs.

Convergence in the grant group The start-up grant initially had a strong effect on self employment. After 1 year, $41 \%$ of this arm were engaged in self-employment. In fact, $78 \%$ of the start-up arm attempted self-employment at any time over five years, and most of this experimentation took place within the first year of receiving the treatment (Table 4). There are some lingering effects of this after 5 years. The start-up grant arm are still slightly more likely to be self-employed (not statistically significant). But the fall from 1-year levels of self-employment is precipitous, suggesting that even this occupational choice impact may be converging.

This finding runs counter to the notion that individuals in our sample would be successful in entrepreneurial work if they could only overcome barriers to starting a small business. The start-up arm induces significantly higher levels of experimentation with self-employment employment. But the large number of people who were induced to start small enterprises do not appear to have stuck with them five years later.

Figures A.I, A.II, and A.III in the appendix show alluvial diagrams, which plot occupational transitions between the baseline and both endlines, for individuals in the control, grant, and factory-job groups, respectively. These figures illustrate two broad forces driving the convergence in occupational choice between the grant-group and the control group from year 1 to year 5. First, we observe a high rate of exit from self-employment into unemployment to wage unemployment in the grant group, suggesting that not everyone who experimented with self-employment enjoyed a high rate of return. Second, we observe a high 
Figure 2: Employment status and program impacts for work in past 2 weeks after 1 and 5 years
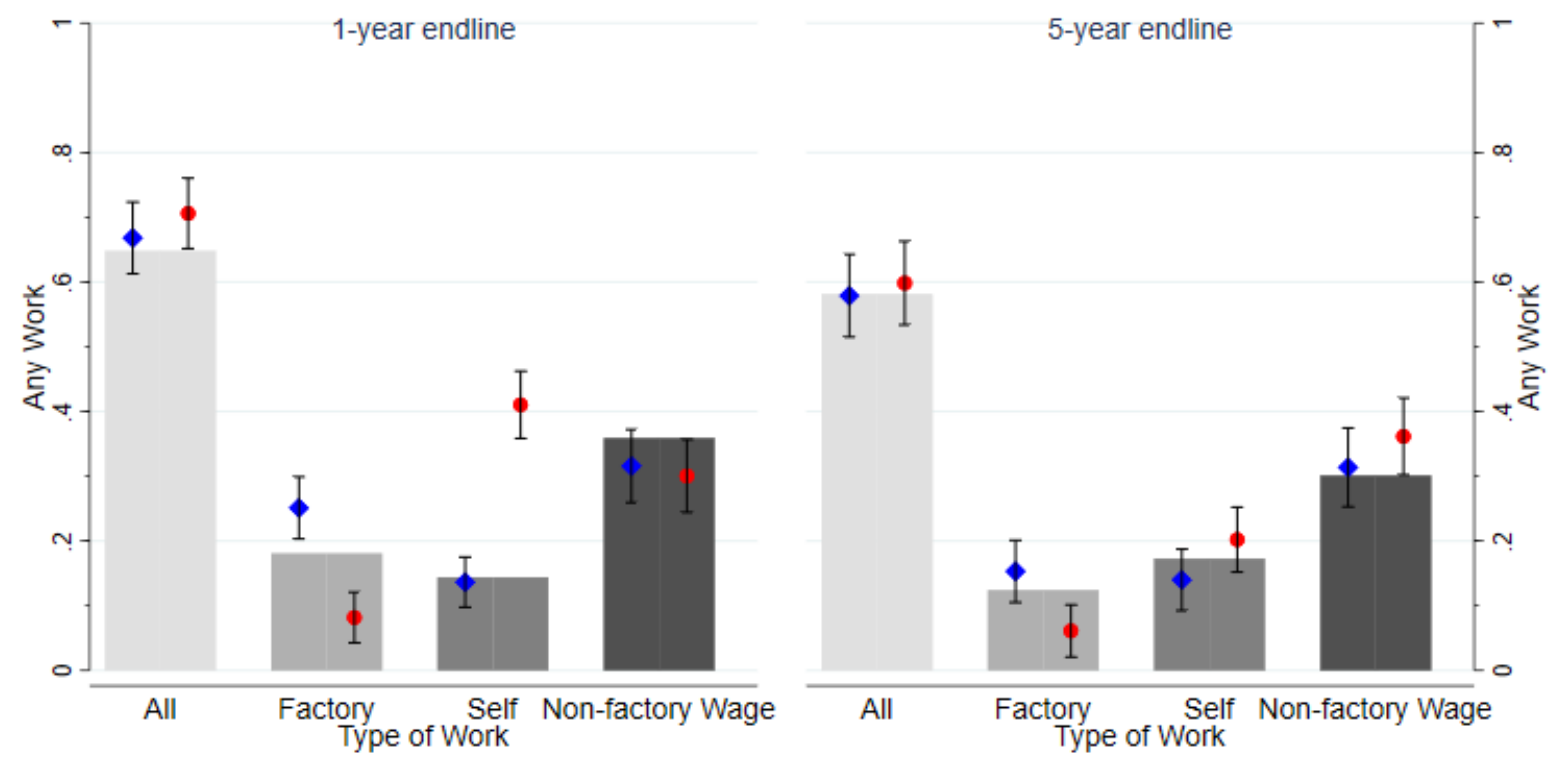

Control Mean

Job offer

Start-up grant

$90 \% \mathrm{Cl}$ for treatment effect

Note: Figure shows average occupational participation rates by treatment status for the 1-year endline (left-hand panel) and the 5-year endline (right-hand panel). Bars in grayscale show the control mean for each occupation, while the blue and red dots shows the control mean plus the estimated treatment effect for the job and grant groups, respectively. Treatment effects are estimated using Equation 1 and confidence intervals are shown for those estimates. We show the average of occupational participation rates across the two rounds of data collection for each endline. Results are similar if we look at different rounds of data separately.

rate of transition into self-employment from other occupations in the control group from year 1 to year 5 . It seems that those individuals with high returns to self-employment would have found their way into it over time, without the help of the grant.

We find no evidence in the short-run data to suggest that these initial effects of the cash grant would be short-lived. Not only had most grant recipients used them for starting microenterprises, they invested most of the grant money into those activities. Table A.VI in the Appendix shows a breakdown of the uses of the grants. Roughly $55 \%$ of the grant money was used on business expenses, and only $7.7 \%$ was reported as used for consumption. Table A.VIII in the Appendix shows the impact on productive assets from our 1-year household survey. The data show a significant effect of the grant on access to land (either owned or rented) specifically for business purposes. We find no such effect on land use for agricultural purposes, but do find increased ownership of livestock. ${ }^{27}$

\footnotetext{
${ }^{27}$ We find no significant effect on a non-exhaustive list of productive assets including sewing machines,
} 
We also find no evidence that that grant-recipients engaged in particularly low-productivity activities. In the Appendix, Table A.VII shows the effects of the interventions on a detailed set of occupational categories. The grants group saw significant increases in the likelihood of engaging in food or drinks sales, or engaging in other forms of trade. They also saw shift into self-employment in agriculture, including animal rearing, which is partly offset by a reduction in farm wage labor. ${ }^{28}$ Column 9 shows that these are not particularly low-earning occupations, as measured by average earnings in the control group in year $5 .^{29}$

Exit from factory work One of the other patterns we see across the five years of the study is rapid exit from factory work. To understand the rapid rate of exit from factory jobs, we begin with evidence from Blattman and Dercon (2018), where we analyzed the first year of qualitative data and patterns in the panel. A few findings stand out:

- We saw no evidence of an industrial wage premium in our five firms. A simple nonexperimental wage comparison suggested that industrial jobs seemed to pay almost a quarter lower wages than informal opportunities.

- Industrial work came with more stable employment hours, though only modestly so. Most members of the control arm were able to find full-time informal work by the time of the 1-year endline. Informal work also tended to pay higher wages than the industrial firms, but it typically came with the risk of short unemployment spells. Over the horizon of a month or a year, however, earnings in the industrial sector were no more stable than the alternatives.

- A third of people offered an industrial job quit the study firm in the first month, and 77 percent quit within the year. People generally quit the sector altogether, rather than simply switch firms. Firm managers said they found the high levels of turnover inconvenient, but were generally able to fill the positions with other low-skill workers.

- Qualitatively, our interviews suggested that young people used low-skill industrial jobs more as a safety net than a long-term job, and where self-employment and informal work were typically preferred to, and more profitable than, industrial jobs.

stoves and refrigerators.

${ }^{28}$ Note that these occupational categories are not mutually exclusive. Many respondents worked in more than one occupational category. We find that the grant induced an increase in the probability of engaging in more than one occupation, and more than doubled the probability of doing both self-employed farming and a petty retail trade.

${ }^{29}$ For example, work in food and drinks sales is a reasonably high-paying occupation; individuals who used the grant to enter this occupation just did not stick with those jobs after 5 years. 
What do we see in the subsequent four years? First, looking again at Figure 2, participation in factory work has declined in the control group between the 1- and 5-year endlines, falling from $18 \%$ to below $12 \%$ at the extensive margin. In other words, the high rate of exit from factory jobs continued after year 1, such that the job-offer individuals are not significantly more likely to be in factory jobs five years later.

Even though few are employed in factories at the 5-year endline, the control group continued to experiment with factory work at a similar pace as they did in the first year of the study. (As Table 4 shows, the control group had on average 2 months of factory work by the one year follow up, and 5 months by the five-year follow up.)

Even after 5 years, the job offer results in nearly 3 additional months of lifetime experience in factories - a one third increase over the control group mean. About half of this gain comes from the first year after the offer. About half comes in the subsequent 3 years (not statistically significant). The small but steady exposure of the control group to factory work bolsters the earlier interpretation that these are unpleasant jobs that our sample used as a last resort.

We also see that the start-up grant deters people from trying factory work, to some extent. After 5 years, the start-up arm are significantly less likely to be engaged in factory work, and have less than half as many months of cumulative factory experience. We can also interpret this as consistent with unemployed workers seeking factory work as a last resort in times of need. The start-up grant had higher incomes after 1 year, allowing them to avoid factory work for a time.

Finally, we see no evidence that these spells of factory employment have effects on long term incomes or hours of work. Appendix Table A.IV reports the complier average causal effect of assignment to the job offer or start-up grant, where we use assignment to treatment as an instrument for length of time in the industrial sector. That is, we use the estimates in Table 4 as a "first stage". This instrumental variables (IV) estimate is useful for understanding whether a longer spell of past employment in the industrial sector has long term effects on outcomes such as income and employment. For instance, the spell could lead to experience, social networks, or shocks that improve or hinder future employment prospects. The instrument is weak by the 5-year endline, since the cumulative effect on months of employment has fallen to 3 months (a $33 \%$ increase). This contributes to noisy IV estimates. Nonetheless, we see nothing to suggest that employment or income prospects improve with longer spells of factory employment. If anything there is a small but noisy adverse effect on incomes and employment levels. 
Table 4: Effect on time spent in factory and self-employment work since baseline

\begin{tabular}{|c|c|c|c|c|}
\hline \multirow[b]{2}{*}{ Outcome } & \multirow{2}{*}{$\begin{array}{c}\text { Control } \\
\text { mean } \\
(1)\end{array}$} & \multirow[b]{2}{*}{$\begin{array}{l}\mathrm{N} \\
(2) \\
\end{array}$} & \multicolumn{2}{|c|}{ ITT Estimate } \\
\hline & & & $\begin{array}{c}\text { Job offer } \\
(3)\end{array}$ & $\begin{array}{c}\text { Start-up } \\
(4)\end{array}$ \\
\hline \multicolumn{5}{|l|}{ Panel A: Factory employment } \\
\hline Any factory work since baseline & 0.414 & 723 & $\begin{array}{c}0.288^{* * *} \\
{[0.044]}\end{array}$ & $\begin{array}{c}-0.212^{* * *} \\
{[0.043]}\end{array}$ \\
\hline Months of factory work since baseline & 9.374 & 723 & $\begin{array}{l}3.186^{*} \\
{[1.624]}\end{array}$ & $\begin{array}{c}-5.438^{* * *} \\
{[1.356]}\end{array}$ \\
\hline Months of factory work by 1 -year follow up & 2.213 & 644 & $\begin{array}{c}1.330^{* * *} \\
{[0.377]}\end{array}$ & $\begin{array}{c}-1.323^{* * *} \\
{[0.326]}\end{array}$ \\
\hline Months of factory work in 3 years between surveys & 5.350 & 723 & $\begin{array}{c}1.564 \\
{[1.132]}\end{array}$ & $\begin{array}{c}-3.066^{* * *} \\
{[0.948]}\end{array}$ \\
\hline Months of factory work in year before 5 -year follow-up & 2.123 & 723 & $\begin{array}{c}0.294 \\
{[0.447]}\end{array}$ & $\begin{array}{c}-1.128 * * * \\
{[0.392]}\end{array}$ \\
\hline \multicolumn{5}{|l|}{ Panel B: Self employment } \\
\hline Any self employment since baseline & 0.441 & 723 & $\begin{array}{l}-0.002 \\
{[0.046]}\end{array}$ & $\begin{array}{c}0.343^{* * *} \\
{[0.042]}\end{array}$ \\
\hline Months of self employment since baseline & 8.899 & 723 & $\begin{array}{l}-1.972 \\
{[1.549]}\end{array}$ & $\begin{array}{c}4.563^{* * *} \\
{[1.445]}\end{array}$ \\
\hline Months of self employment by 1-year follow up & 1.985 & 644 & $\begin{array}{l}-0.376 \\
{[0.393]}\end{array}$ & $\begin{array}{c}3.822^{* * *} \\
{[0.465]}\end{array}$ \\
\hline Months of self employment in 3 years between surveys & 4.447 & 723 & $\begin{array}{l}-0.997 \\
{[1.223]}\end{array}$ & $\begin{array}{c}0.614 \\
{[1.000]}\end{array}$ \\
\hline Months of self employment in year before 5 -year follow-up & 2.784 & 723 & $\begin{array}{l}-0.703 \\
{[0.474]}\end{array}$ & $\begin{array}{c}0.363 \\
{[0.476]}\end{array}$ \\
\hline
\end{tabular}

${ }^{*}$ indicates $p<.1,{ }^{* *}$ indicates $p<.05$, and ${ }^{* * *}$ indicates $p<.01$. Regression estimates are calculated with district and cohort fixed effects Standard errors are clustered at the level of the respondent due to having two observations per person. All observations are weighted by the inverse of their sampling probability and the inverse of their predicted probability of attrition using a Leave-One-Out logistic predictive method. Control means are also calculated using these weights. In the last two columns we report t-tests for the equivalence of the main experimental coefficients across the 1-year and 5-year endlines. For example in Column (8), row (1) reports the p-value for the test that coefficients in Columns (3) and (6) are equal. 
Comparison to representative data The trends in employment and occupational choice that we observe in our control group raise questions about how informative our results might be about young women in Ethiopia more generally. Notably, we observe rapid increases in wages in the first year of the study, but then mostly flat average earnings and hours over the following four years. Our sample is made up of young adults in a rapidly growing economy. Could wages for this demographic really be stagnant over this time period?

We study earnings using six repeated cross-sections of representative urban labour force survey data from the Ethiopian Statistical Statistical Agency over almost exactly the same years as our study (2010 to 2018). To ensure comparability, we restrict our sample to woman in urban areas in Addis Ababa, Oromia and Tigray, where our study was conducted. We then define a cohort of individuals born in the same range of years as individuals in our sample, and reweight by year of birth within this cohort to match the distribution of ages our sample (the average age in our data is 21 in 2010).

Figure 3: Progression of earnings and employment in representative cohort data

(a) Mean employment in the last month

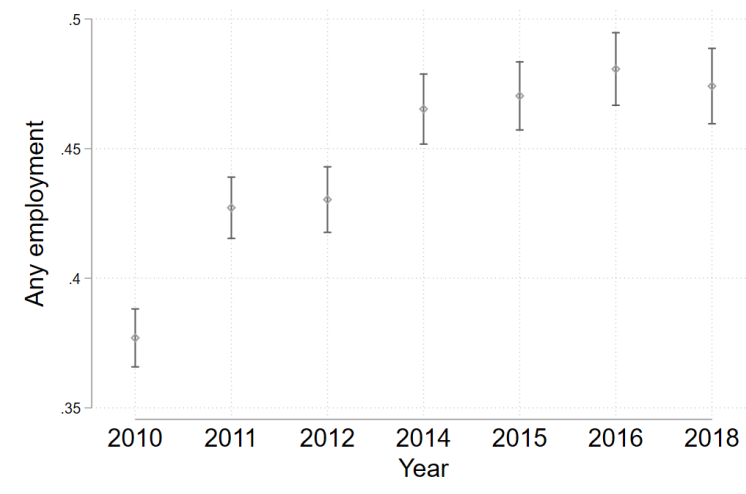

(b) Mean weekly wage earnings over the past month

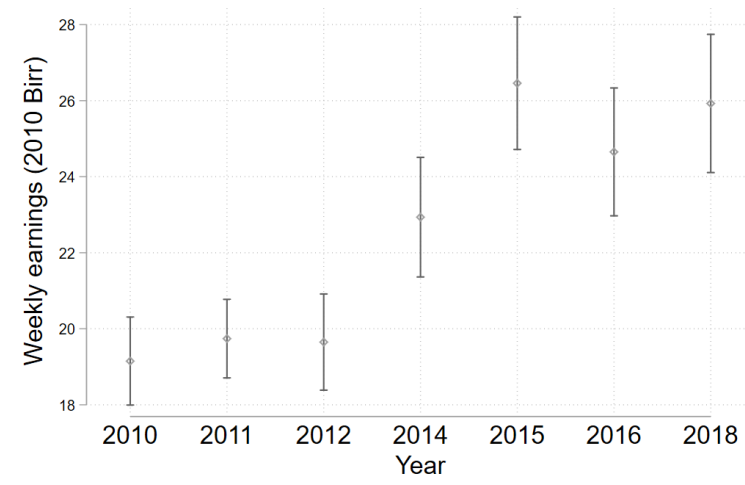


Figure 4: Progression of earnings in representative in two cohorts

(a) Mean employment in the last month for birth year 1985

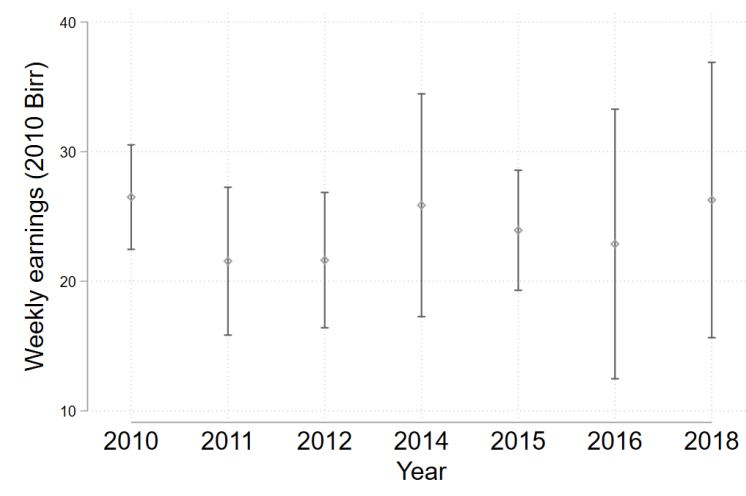

(b) Mean weekly wage earnings over the past month for birth year 1994

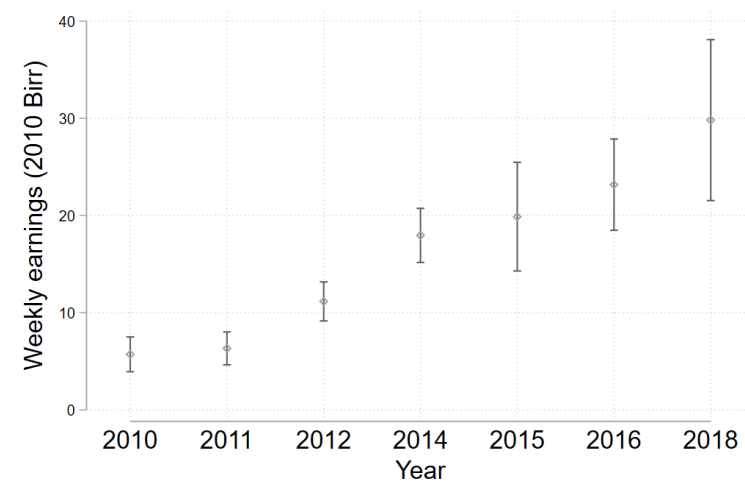

Figure 3 plots the trajectory of employment rates and earnings (deflated to 2010 Birr using official inflation figures). Employment rates and earnings climb during the early years of the study, but plateau after that, when the average age of the cohort reaches roughly 26 . The data suggests that this trajectory is not driven by slowing economic growth over the years of our study, but rather by a cohort effect: employment rates improve quickly for new labour market entrants in their early- to mid-20s but slow down as they age. In Figure 4 we compare the earnings trajectories for women born in 1985 to those born in 1994. Earnings are still growing for those only 23 at the time of our endline in 2017, but have been stagnant for some time those who are 32. In other words, the experience of our study participants is very much consistent with the experience of young people in Ethiopia over this time period.

Cost-benefit analysis Figure 5 shows the net present value of both the job offer and the start-up grant interventions. In each survey wave - baseline, 1-year, and 5-year - we report the treatment effects of the interventions on earnings and linearly interpolate between them. We take the cumulative sum of such treatment effects across all 5 years and discount the sum at a $5 \%$ annualized rate. This gives us a relatively generous estimate of the net present value..$^{30}$

\footnotetext{
${ }^{30}$ Note that the estimates in Figure 5 extrapolate directly from the baseline to year 1 treatment effects. We know from recall data that the effects on employment rates in the months after treatment were likely larger than by the time of the first endline, as respondents took up self-employment and factory work and then quit quickly. Taking into account this additional employment would inflate our total earnings calculations. However, we do not have well-identified causal estimates of the effects of earnings in this interim time period. Using recall data to estimate a the total increase in months of work during that first year and using back-ofenvelope calculations of how that increased employment translates into earnings at average prevailing wages, we still find that the NPV of both interventions lies well below their respective costs. These estimates are
} 
Figure 5: Net present value of intervention according to treatment effects on income

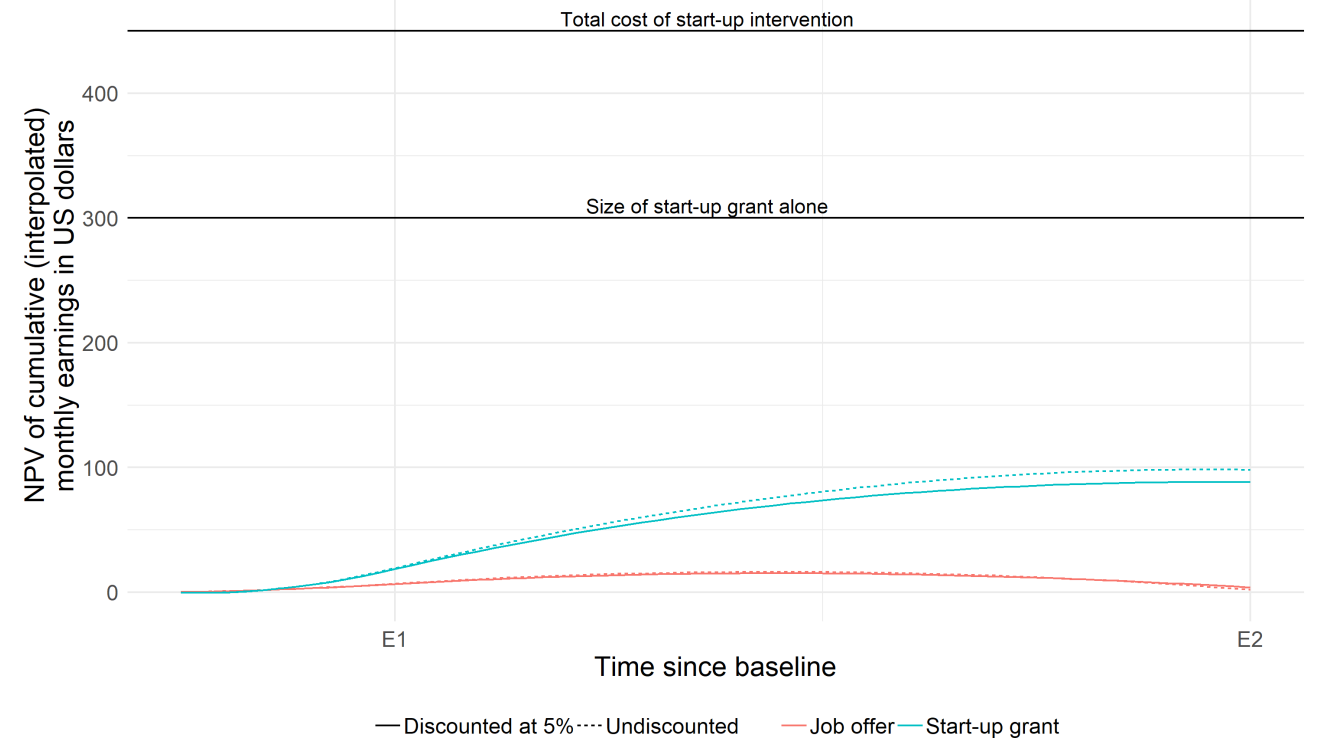

The figure shows how far the start-up grant intervention is from being a cost-effective program of poverty reduction, in comparison to its $\$ 300$ grant amount and $\$ 450$ total operating cost. As noted in Blattman and Dercon (2018), the effects on earnings of the start-up grant after 1 year amounted to only $16 \%$ of the total $\$ 300$ grant amount.

\subsection{Health impacts}

One year after receiving the job offers, we found evidence of reduced health outcomes, as measured by self-reported ability to perform activities of daily life, among those who were assigned to the factory job. Did these persist?

For the long-run data collection, we collected an expanded set of health measures from the first endline survey. First, we used an expanded list of fifteen activities to improve our measurement of ability to perform activities of daily activities, ranging from 0 to 45 . Second, we conducted a comprehensive questionnaire covering a list of twenty symptoms of ill health. Here respondents could report the regularity with which they experienced these physical symptoms from zero (never) to three (often), without having to be diagnosed with a particular condition. Third, we asked about four specific health conditions that are particularly common among individuals working in industrial work, namely: asthma, respiratory problems, dermatitis, and carpal tunnel. Fourth, to more accurately measure respiratory health, and verify our self-reported measures, we conducted a spirometry procedure. Here

presented in Table A.IV. The estimates with these earnings estimates taken into account are labelled as "maximum". 
Table 5: Impacts on health

\begin{tabular}{|c|c|c|c|c|c|c|c|c|}
\hline \multirow[b]{3}{*}{ Outcome } & \multicolumn{3}{|c|}{ 1-year Endline } & \multicolumn{3}{|c|}{ 5-year Endline } & \multirow{2}{*}{\multicolumn{2}{|c|}{$\begin{array}{c}\text { Cross-year difference } \\
\text { p-value }\end{array}$}} \\
\hline & \multirow{2}{*}{$\begin{array}{c}\text { Control } \\
\text { mean } \\
(1)\end{array}$} & \multicolumn{2}{|c|}{ ITT Estimate } & \multirow{2}{*}{$\begin{array}{c}\text { Control } \\
\text { mean } \\
(4)\end{array}$} & \multicolumn{2}{|c|}{ ITT Estimate } & & \\
\hline & & $\begin{array}{l}\text { Job } \\
(2)\end{array}$ & $\begin{array}{c}\text { Grant } \\
(3)\end{array}$ & & $\begin{array}{l}\text { Job } \\
(5)\end{array}$ & $\begin{array}{c}\text { Grant } \\
(6)\end{array}$ & $\begin{array}{l}\text { Job } \\
(7)\end{array}$ & $\begin{array}{l}\text { Grant } \\
(8)\end{array}$ \\
\hline Physical health, z-score & 0.058 & $\begin{array}{c}-0.193^{* * *} \\
{[0.066]}\end{array}$ & $\begin{array}{l}-0.096 \\
{[0.062]}\end{array}$ & -0.001 & $\begin{array}{c}0.006 \\
{[0.066]}\end{array}$ & $\begin{array}{c}0.092 \\
{[0.076]}\end{array}$ & 0.024 & 0.031 \\
\hline Ability to do 5 core activities of daily life $(0-15)$ & 14.072 & $\begin{array}{c}-0.274^{* *} \\
{[0.125]}\end{array}$ & $\begin{array}{l}-0.236^{*} \\
{[0.128]}\end{array}$ & 13.486 & $\begin{array}{l}-0.129 \\
{[0.188]}\end{array}$ & $\begin{array}{l}-0.091 \\
{[0.195]}\end{array}$ & 0.484 & 0.496 \\
\hline Ability to do 15 activities of daily life (0-45) & & & & 39.244 & $\begin{array}{l}-0.261 \\
{[0.470]}\end{array}$ & $\begin{array}{c}0.199 \\
{[0.539]}\end{array}$ & 0.579 & 0.712 \\
\hline Disability & 0.040 & $\begin{array}{c}0.033^{* *} \\
{[0.015]}\end{array}$ & $\begin{array}{c}0.017 \\
{[0.014]}\end{array}$ & 0.022 & $\begin{array}{c}0.009 \\
{[0.011]}\end{array}$ & $\begin{array}{c}0.012 \\
{[0.014]}\end{array}$ & 0.170 & 0.778 \\
\hline Subjective health assessment $(0-10)$ & 8.909 & $\begin{array}{c}-0.233^{* *} \\
{[0.104]}\end{array}$ & $\begin{array}{c}0.003 \\
{[0.104]}\end{array}$ & 8.768 & $\begin{array}{c}0.071 \\
{[0.106]}\end{array}$ & $\begin{array}{c}0.156 \\
{[0.102]}\end{array}$ & 0.025 & 0.246 \\
\hline Subjective health assessment, 5 years from now (-10 to 10$)$ & 0.760 & $\begin{array}{c}0.055 \\
{[0.093]}\end{array}$ & $\begin{array}{l}-0.002 \\
{[0.091]}\end{array}$ & 0.100 & $\begin{array}{l}-0.062 \\
{[0.084]}\end{array}$ & $\begin{array}{c}0.125 \\
{[0.083]}\end{array}$ & 0.328 & 0.291 \\
\hline General health $(0-60)$ & & & & 56.902 & $\begin{array}{c}0.435 \\
{[0.310]}\end{array}$ & $\begin{array}{c}0.345 \\
{[0.326]}\end{array}$ & 0.162 & 0.290 \\
\hline Physical sympton count (1-5) & & & & 0.207 & $\begin{array}{l}-0.030 \\
{[0.034]}\end{array}$ & $\begin{array}{l}-0.002 \\
{[0.034]}\end{array}$ & 0.371 & 0.949 \\
\hline Abnormal Spirometry Reading (colour system) & & & & 0.020 & $\begin{array}{c}0.016 \\
{[0.020]}\end{array}$ & $\begin{array}{l}-0.003 \\
{[0.019]}\end{array}$ & 0.421 & 0.880 \\
\hline Mental health and subjective well-being, z-score & -0.112 & $\begin{array}{c}0.078 \\
{[0.070]}\end{array}$ & $\begin{array}{c}0.224^{* * *} \\
{[0.064]}\end{array}$ & 0.004 & $\begin{array}{l}-0.056 \\
{[0.075]}\end{array}$ & $\begin{array}{c}0.024 \\
{[0.067]}\end{array}$ & 0.177 & 0.024 \\
\hline Depression symptoms $(0-27)$ & 2.545 & $\begin{array}{l}-0.088 \\
{[0.219]}\end{array}$ & $\begin{array}{l}-0.278 \\
{[0.211]}\end{array}$ & 2.283 & $\begin{array}{c}0.132 \\
{[0.261]}\end{array}$ & $\begin{array}{l}-0.147 \\
{[0.244]}\end{array}$ & 0.501 & 0.671 \\
\hline Generailized Anxiety index $(0-27)$ & 2.028 & $\begin{array}{c}0.053 \\
{[0.197]}\end{array}$ & $\begin{array}{l}-0.279 \\
{[0.183]}\end{array}$ & 1.919 & $\begin{array}{c}0.216 \\
{[0.240]}\end{array}$ & $\begin{array}{l}-0.013 \\
{[0.210]}\end{array}$ & 0.588 & 0.321 \\
\hline
\end{tabular}

${ }^{*}$ indicates $p<.1,{ }^{* *}$ indicates $p<.05$, and ${ }^{* * *}$ indicates $p<.01$. Regression estimates are calculated with district and cohort fixed effects Standard errors are clustered at the level of the respondent due to having two observations per person. All observations are weighted by the inverse of their sampling probability and the inverse of their predicted probability of attrition using a Leave-One-Out logistic predictive method. Control means are also calculated using these weights. In the last two columns we report t-tests for the equivalence of the main experimental coefficients across the 1-year and 5-year endlines. For example in Column (8), row (1) reports the p-value for the test that coefficients in Columns (3) and (6) are equal.

we followed guidelines from the European Respiratory Society, reported in Moore (2012). For the main results we report on indicator for whether the spirometry test shows an abnormal reading, indicating a respiratory problem.

In the pre-analysis plan we committed to report the effect of the two treatments on these four aggregate measures. Table 5 shows these results. We do not find evidence that these negative health effects persist. Health outcomes are not significantly different for either treatment group across a wide range of measures. Crucially, the coefficient on our primary health outcome (our physical health z-score) is significantly smaller at 5 years than at 1 year. Whereas the coefficient on physical health was -0.193 standard deviations after 1 year (significant at the 1\% level), the coefficient is .007 standard deviations after 5 with a standard error of 0.068 . Only adverse health effects greater than -0.15 standard deviations are outside the $95 \%$ confidence interval. The change in the disability indicator is similar, though for the indicator the 1- and 5-year difference is not statistically significant. We also check for 
adverse health effects on children of treated parents and find no evidence of this (see Table A.III in the Appendix).

There are two possible interpretation of these findings. The first is that the maladies experienced one year after receiving the factory job offer were not chronic. The second is that the control group was exposed to hazardous factory work in the interim and have experienced the same health problems as a result. The evidence favors the first explanation.

First, in absolute terms, the sample is in good health, perhaps even slightly improved over time. Serious disability rates after 5 years are half of what they were after 1 year, suggesting many of the problems reported in the previous endline were temporary. Second, we see no evidence that those who stayed longer in factory work have poorer health. Appendix Table A.V reports complier average causal effects using assignment to treatment as an instrument for length of time in the industrial sector (see Table 4). After 1-year, these IV estimates showed serious adverse effects on health. After 5 years we see no such evidence. While it is true that the instrument is considerably weaker after 5 years, the IV estimate for physical health or serious disabilities is close to zero, and the confidence interval does not include the 1-year point estimate.

\subsection{Robustness}

We run robustness checks to investigate whether our results could be driven by differential rates of attrition. First, we consider the fact that we conducted two rounds of surveying at our final endline, and did not find everyone at both rounds. If individuals that were harder to track are systematically different, we should also expect that individuals that we found at both endlines would be different to those that we found only once. In column 2 of Table 6 we reestimate our main treatment effects restricting our sample only to those that responded to both surveys. We find very little difference in the main coefficients for either treatments.

Next, following Lee (2009), we drop extreme values in each treatment arm such that the total number of observations is equal to that in the group with the lowest response rate (in our case, the factory job group). We do this first by dropping the highest and then lowest values from the least attrited arms such that the sample size is the same as the most attrited arms, then re-estimating our main treatment effects, in order to establish Lee Bounds. These results are presented in Table 6. We find that the higher bound of the effect of the grant is still not significantly different zero, though we cannot rule out a significantly negative effect of the grant under these extreme assumptions about attrition. None of the estimated bound for the job group are statistically different from zero.

For further robustness, we estimate bounds following Karlan and Valdivia (2011) and 
Blattman, Fiala, and Martinez (2014) by making different assumptions about missing data. For upper bounds we impute the 40th percentile of control group to missing values in the control and the 60th percentile to missing values in the treatment groups. For the lower bounds we do the opposite. Again, we find no effect of the grant at the upper bound, but cannot rule out a negative effect on employment at the lower bound. In all, these robustness checks are consistent with our claim that the grant treatment does not have positive long-run employment effects.

\section{Discussion and conclusions}

We report on the labor market trajectories of almost 1000 young and mostly unemployed women in Ethiopia. We also report on two interventions that many have reasonably proposed could have had large and lasting effects on long run labor market outcomes: among people appearing to queue for industrial employment, offering an entry-level factory job in a country that is just beginning to industrialize; and offering approximately one year of factory wages as a cash grant plus some business training.

We learn both from the descriptive analysis of the panel and the experiments. We find, after five years, no evidence that either intervention has any effect on the likelihood to still work that sector after 5 years, compared to the control group (although the start-up grant group were less likely to experiment with factory employment). Earnings and consumption are also not perceptibly different in any of these groups, and we can exclude improvements as small as 0.1 standard deviations in economic outcomes. The labor market choices and outcomes for our population have roughly the same structure and earnings that the treated would have had without the intervention.

This is doubly important because of the promising short-term evidence that the startup grant increased productivity and earnings by a third. Within 5 years, however, these productivity gains seem to have dissipated.

There are reasons to believe these (mostly) young women did not have high sustained returns to self-employment relative to non-industrial wage work. The businesses may simply have failed or faded away gradually over time, as the women failed to reinvest earnings in the business. It is also possible that the business was simply a form of savings and consumption smoothing in an economy where the real interest rate from cash savings is as low as -15-

$-20 \%$ due to high inflation and the high cost of local savings institutions (which offer negative nominal interest rates). Investing in a small enterprise may simply be the most efficient way of maximizing consumption of a grant. For instance, at a real interest rate of $-15 \%$, a 5000 birr grant could be consumed completely in 5 years by spending 54 birr per month. But at 


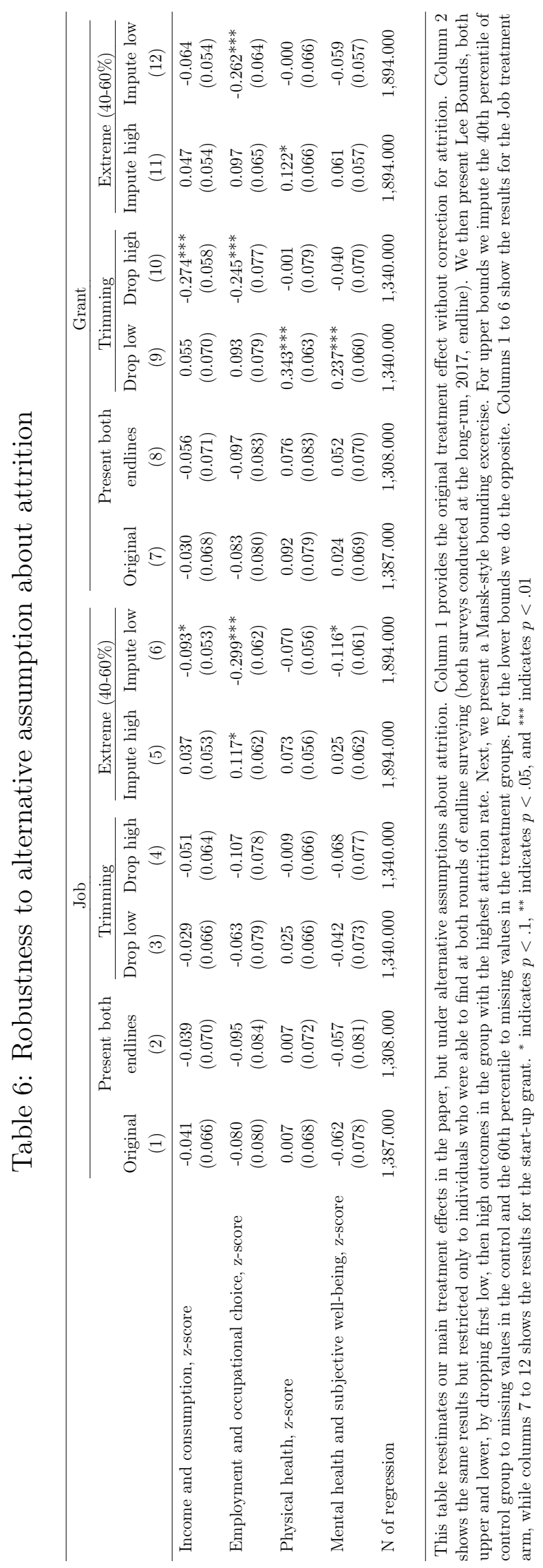


a real interest rate of $5 \%$ for example (supposing this is what a business or other savings vehicle could earn), a 5000 birr grant could provide a monthly payment of 94 per month over the same period, almost double.

Plausibly, the number of constraints on entrepreneurial success in this setting meant that lifting a single, marginal constraint such as investment capital is not enough to have a lasting return for this particular group of young mainly female workers. Given that many of the microenterprises folded, we suspect that low returns to capital given other barriers is a likely factor. Of course, it is also possible that our sample - drawn from a population queuing for a factory job - are per definition not terribly representative, nor full of entrepreneurial talent. Still, evidence points to a large number of them regularly engaging in some self-employment as a temporary alternative to wage work.

Our results also bolster a view that industrial work is not particularly high-quality, and not particularly skilled and high-paying (at least at this stage of development in Ethiopia). Wages were no better than in other low-paid sectors, jobs were unpleasant and seemingly hazardous, and (most worryingly) those that spent more months in factory work reported more serious health problems after one year. Nevertheless, for some it offered another employment option seemingly worth taking, at least for some time during the five years studied.

Naturally there are limits to what we can learn from five sites and five firms. Yet the same is true of any single program evaluation. Our start-up program is comparable in many respects to a suite of anti-poverty programs that give youth start-up capital, and the industrial results speak to low-skill light industry in contexts where workers are effectively disposable to firms.

\section{References}

Abebe, Girum, Niklas Buehren, and Markus Goldstein (2020). "Short-Run Welfare Impacts of Factory Jobs."

Abebe, Girum, Stefano Caria, Marcel Fafchamps, et al. (2018). "Anonymity or Distance? Job Search and Labour Market Exclusion in a Growing African City." Working paper.

Abebe, Girum, Stefano Caria, and Esteban Ortiz-Ospina (2017). "The selection of talent:

Experimental and structural evidence from Ethiopia." Working paper.

Abel, Martin, Rulof Burger, and Patrizio Piraino (2017). The value of reference letters.

Akerlof, George A. and Janet L. Yellen (1986). Efficiency wage models of the labor market. Cambridge University Press.

Arulampalam, Wiji, Paul Gregg, and Mary Gregory (2001). "Unemployment scarring." The Economic Journal 111.475, pp. 577-584. 
Atkin, David (2009). "Working for the Future: Female Factory Work and Child Health in Mexico." Working paper.

Balboni, Clare et al. (2020). "Why do people stay poor?"

Bandiera, Oriana et al. (2013). "Can entrepreneurship programs transform the economic lives of the poor?" Working paper.

Bandiera, Oriana et al. (2017). "Labor markets and poverty in village economies." The Quarterly Journal of Economics 132.2, pp. 811-870.

Banerjee, Abhijit V. and Esther Duflo (2011). Poor economics: A radical rethinking of the way to fight global poverty. New York: Public Affairs.

Banerjee, Abhijit V and Andrew F Newman (1993). "Occupational choice and the process of development." Journal of political economy 101.2, pp. 274-298.

Banerjee, Abhijit, Dean Karlan, and Jonathan Zinman (2015). "Six Randomized Evaluations of Microcredit: Introduction and Further Steps." American Economic Journal: Applied Economics 7.1, pp. 1-21.

Bassi, Vittorio and Aisha Nansamba (2017). "Information Frictions in the Labor Market: Evidence from a Field Experiment in Uganda." Working Paper.

Beaman, Lori et al. (2014). Self-Selection into Credit Markets: Evidence from Agriculture in Mali. Working Paper 20387. National Bureau of Economic Research.

Beegle, Kathleen et al. (2012). "Methods of household consumption measurement through surveys: Experimental results from Tanzania." Journal of Development Economics 98.1, pp. $3-18$.

Bernard, Andrew B., Raymond Robertson, and Peter K. Schott (2010). "Is Mexico a Lumpy Country?" en. Review of International Economics 18.5, pp. 937-950.

Bianchi, Milo and Matteo Bobba (2013). "Liquidity, Risk, and Occupational Choices." Review of Economic Studies 80.2, pp. 491-511.

Blattman, Christopher, Jeannie Annan, et al. (2016). "The returns to microenterprise support among the ultra-poor: A field experiment in postwar Uganda." American Economic Journal: Applied Economics 8.2, pp. 35-64.

Blattman, Christopher and Stefan Dercon (2018). "The impacts of industrial and entrepreneurial work on income and health: Experimental evidence from Ethiopia." American Economic Journal: Applied Economics 10.3, pp. 1-38.

Blattman, Christopher, Nathan Fiala, and Sebastian Martinez (2014). "Generating skilled employment in developing countries: Experimental evidence from Uganda." Quarterly Journal of Economics 129.2, pp. 697-752. 
Blattman, Christopher, Nathan Fiala, and Sebastian Martinez (2019). "The Long Term Impacts of Grants on Poverty: 9-Year Evidence from Uganda's Youth Opportunities Program." American Economic Review: Insights, forthcoming.

Blattman, Christopher, Julian Jamison, and Margaret Sheridan (2017). "Reducing crime and violence: Experimental evidence on cognitive behavioral therapy in Liberia." American Economic Review 107.4, pp. 1165-1206.

Blattman, Christopher and Laura Ralston (2015). "Generating employment in poor and fragile states: A review of the evidence from labor market and entrepreneurship programs." Working paper.

Brudevold-Newman, Andrew Peter et al. (2017). "A firm of one's own: experimental evidence on credit constraints and occupational choice." Working paper.

Card, David (1996). "The Effect of Unions on the Structure of Wages: A Longitudinal Analysis." Econometrica 64.4, pp. 957-979.

CSA (2011). Report on large and medium manufacturing industries survey 2009-2010. Tech. rep. Addis Abada: Central Statistical Authority.

El Badaoui, E., E. Strobl, and F. Walsh (2008). "Is There an Informal Employment Wage Penalty? Evidence from South Africa." Economic Development and Cultural Change 56, pp. 683-710.

Fafchamps, Marcel et al. (2014). "When is capital enough to get female microenterprises growing? Evidence from a randomized experiment in Ghana." Journal of Development Economics 106.1, pp. 211-226.

Fiala, Nathan (2018). "Returns to microcredit, cash grants and training for male and female microentrepreneurs in Uganda." World Development 105, pp. 189-200.

Fields, Gary S. (1975). "Rural-urban migration, urban unemployment and underemployment, and job-search activity in LDCs." Journal of development economics 2.2, pp. 165-187.

Gertler, Paul, Sebastian Martinez, and Marta Rubio (2012). "Investing Cash Transfers to Raise Long Term Living Standards." American Economic Journal: Applied Economics. 164-192 4.1, pp. 164-192.

Getahun, Tigabu D. and Espen Villanger (2016). "Labor-intensive jobs for women and development: Intrahousehold welfare effects and its transmission channels." Working paper.

Harris, John R. and Michael P. Todaro (1970). "Migration, unemployment and development: a two-sector analysis." The American Economic Review 60.1, pp. 126-142.

Haushofer, Johannes and Jeremy Shapiro (2016). "The short-term impact of unconditional cash transfers to the poor: Experimental evidence from Kenya." The Quarterly Journal of Economics 131.4, pp. 1973-2042. 
Haushofer, Johannes and Jeremy Shapiro (2018). "The Long-Term Impact of Unconditional Cash Transfers: Experimental Evidence from Kenya." Working paper.

Hewett, P. and S. Amin (2000). "Assessing the Impact of Garment Work on Quality of Life Measures." Discussion paper, Population Council.

Hussam, Reshmaan, Natalia Rigol, and Benjamin Roth (2017). "Targeting high ability entrepreneurs using community information: Mechanism design in the field." Working paper.

Kabeer, N. (2002). The Power to Choose: Bangladeshi Garment Workers in London and Dhaka. London: Verso.

Karlan, Dean, Robert Osei, et al. (2014). "Agricultural decisions after relaxing credit and risk constraints." The Quarterly Journal of Economics 129.2, pp. 597-652.

Karlan, Dean and Martin Valdivia (2011). "Teaching entrepreneurship: Impact of business training on microfinance clients and institutions." Review of Economics and statistics 93.2 , pp. $510-527$.

Katz, Lawrence F. et al. (1989). "Industry Rents: Evidence and Implications." Brookings Papers on Economic Activity. Microeconomics 1989, pp. 209-290.

Kroft, Kory, Fabian Lange, and Matthew J Notowidigdo (2013). "Duration dependence and labor market conditions: Evidence from a field experiment." The Quarterly Journal of Economics 128.3, pp. 1123-1167.

Lee, David S (2009). "Training, wages, and sample selection: Estimating sharp bounds on treatment effects." The Review of Economic Studies 76.3, pp. 1071-1102.

Lewis, W. Arthur (1954). "Economic development with unlimited supplies of labor." Manchester School 22.2, pp. 139-191.

McKenzie, David (2012). "Beyond baseline and follow-up: The case for more $\mathrm{T}$ in experiments." Journal of Development Economics 99.2, pp. 210-221.

Mel, Suresh de, David J. McKenzie, and Christopher Woodruff (2012). "One-Time Transfers of Cash or Capital Have Long-Lasting Effects on Microenterprises in Sri Lanka." Science 335.6071, pp. 962-966.

Moore, VC (2012). "Spirometry: step by step." Breathe 8.3, pp. 232-240.

Pissarides, Christopher A (2011). "Equilibrium in the labor market with search frictions." American Economic Review 101.4, pp. 1092-1105.

Söderbom, Måns and F. Teal (2004). "Size and efficiency in African manufacturing firms: evidence from firm-level panel data." Journal of Development Economics 73.1, pp. 369394.

The Economist (2014). "An awakening giant." The Economist.

Verhoogen, Eric (2008). "Trade, Quality Upgrading and Wage Inequality in the Mexican Manufacturing Sector." Quarterly Journal of Economics 123.2, pp. 489-530. 
Online appendix 


\section{Appendix Table A.I: Covariate balance at baseline only for individuals who responded to}

the second endline

\begin{tabular}{|c|c|c|c|c|c|}
\hline \multirow[b]{2}{*}{$\begin{array}{l}\text { Baseline covariates } \\
(\mathrm{N} \text {-control }=299, \mathrm{~N} \text {-job }=249, \mathrm{~N} \text {-grant }=250)\end{array}$} & \multirow{2}{*}{$\begin{array}{c}\text { Control } \\
\text { mean } \\
(1)\end{array}$} & \multicolumn{2}{|c|}{ Job-Control } & \multicolumn{2}{|c|}{ Grant-Control } \\
\hline & & $\begin{array}{l}\text { Diff } \\
(2)\end{array}$ & $\begin{array}{c}\text { p-value } \\
(3)\end{array}$ & $\begin{array}{l}\text { Diff } \\
(4)\end{array}$ & $\begin{array}{c}\text { p-value } \\
(5)\end{array}$ \\
\hline Age & 21.98 & 0.20 & 0.53 & 0.05 & 0.88 \\
\hline Female & 0.79 & 0.00 & & -0.00 & \\
\hline Unmarried & 0.80 & -0.05 & 0.19 & -0.04 & 0.26 \\
\hline Muslim & 0.04 & 0.00 & 0.95 & 0.00 & 0.94 \\
\hline Household Size & 4.37 & -0.13 & 0.49 & -0.07 & 0.73 \\
\hline Household head & 0.22 & 0.04 & 0.25 & -0.01 & 0.73 \\
\hline Proportion of household dependents & 0.44 & -0.01 & 0.91 & 0.00 & 0.94 \\
\hline Total years of education and training & 9.43 & -0.37 & 0.11 & -0.18 & 0.46 \\
\hline Executive function, z-score & 0.12 & $-0.19 * *$ & 0.02 & $-0.18^{* *}$ & 0.03 \\
\hline Weekly cash earnings, 2010 Birr & 9.74 & 0.61 & 0.82 & -1.51 & 0.58 \\
\hline Durable assets, z-score & 0.12 & -0.12 & 0.12 & $-0.15^{*}$ & 0.05 \\
\hline Ever worked in a large firm & 0.28 & -0.02 & 0.50 & 0.04 & 0.22 \\
\hline Hrs work/wk, past two weeks & 7.61 & 0.38 & 0.80 & -0.53 & 0.73 \\
\hline No work in past 4 weeks & 0.70 & -0.02 & 0.53 & -0.03 & 0.40 \\
\hline Highest - lowest earnings, past month & 179.96 & $47.56^{* *}$ & 0.04 & 26.25 & 0.13 \\
\hline Could borrow 3000 birr & 0.29 & 0.06 & 0.12 & 0.03 & 0.41 \\
\hline Ability to do activities of daily life $(0-15)$ & 14.32 & 0.11 & 0.35 & 0.08 & 0.45 \\
\hline Disability: Great difficulty at more than 1 activities & 0.01 & -0.01 & 0.43 & -0.00 & 0.58 \\
\hline Risk aversion, z-score & -0.01 & -0.01 & 0.93 & 0.08 & 0.35 \\
\hline Future orientation, z-score & 0.10 & -0.11 & 0.18 & -0.03 & 0.67 \\
\hline Locus of control index & -0.04 & 0.00 & 0.98 & 0.13 & 0.13 \\
\hline Self esteem index, s-score & -0.05 & -0.04 & 0.64 & 0.08 & 0.35 \\
\hline Family relations index, z-score & -0.05 & -0.05 & 0.54 & 0.04 & 0.61 \\
\hline Friends and nieghbors relations index & 0.04 & -0.08 & 0.31 & -0.06 & 0.45 \\
\hline Change in subjective well being, past yr. & 0.23 & 0.13 & 0.19 & 0.11 & 0.22 \\
\hline Symptoms of depression, z-score & -0.01 & -0.00 & 0.97 & -0.02 & 0.80 \\
\hline Symptoms of anxiety, z-score & -0.02 & 0.07 & 0.45 & -0.05 & 0.59 \\
\hline Agressive or hostile behaviors, z-score & 0.03 & -0.10 & 0.22 & -0.13 & 0.15 \\
\hline Conscientiousness index, z-score & 0.02 & -0.05 & 0.56 & 0.02 & 0.85 \\
\hline Years experience, private firm & 0.35 & $0.23^{* *}$ & 0.05 & $0.22^{* *}$ & 0.03 \\
\hline Years experience, workshop & 0.01 & 0.00 & 0.72 & 0.01 & 0.30 \\
\hline Years experience, government/NGO & 0.09 & -0.02 & 0.69 & 0.00 & 0.98 \\
\hline Probability of a better job, next month & 0.68 & 0.00 & 0.89 & -0.01 & 0.81 \\
\hline Probability of full-time work, next month & 0.55 & 0.02 & 0.35 & 0.03 & 0.13 \\
\hline
\end{tabular}

${ }^{*}$ indicates $p<.1{ }^{* *}$ indicates $p<.05$, and ${ }^{* * *}$ indicates $p<.01$. Sample is restricted to only individuals who responded to the endline survey in 2017. Regression estimates are calculated with district and cohort fixed effects. Standard errors are clustered at the level of the respondent due to having two observations per person. 


\section{Appendix Table A.II: Attrition}

\begin{tabular}{|c|c|c|c|c|}
\hline \multirow[b]{3}{*}{$\begin{array}{l}\text { Dependent Variable: Never found at } 5 \text {-year endline } \\
\text { Fraction of sample not found: } .2\end{array}$} & \multicolumn{4}{|c|}{ Attrition and Non-Response } \\
\hline & \multicolumn{2}{|c|}{ Only FE } & \multicolumn{2}{|c|}{ All Covariates } \\
\hline & $\begin{array}{l}\text { Beta } \\
(1)\end{array}$ & $\begin{array}{l}\text { Std. error } \\
\quad(2)\end{array}$ & $\begin{array}{c}\text { Beta } \\
(3)\end{array}$ & $\begin{array}{c}\text { Std. error } \\
\text { (4) }\end{array}$ \\
\hline Job offer & 0.003 & 0.032 & 0.014 & 0.034 \\
\hline Start-up & -0.051 & $0.031^{*}$ & -0.043 & 0.032 \\
\hline Age & & & 0.894 & 1.344 \\
\hline Age squared & & & -0.053 & 0.079 \\
\hline Age cubed & & & 0.001 & 0.002 \\
\hline Age quartic & & & -0.000 & 0.000 \\
\hline Female & & & 0.129 & 0.095 \\
\hline Unmarried & & & 0.045 & 0.034 \\
\hline Muslim & & & 0.233 & $0.071^{* * *}$ \\
\hline Household Size & & & 0.008 & 0.008 \\
\hline Household head & & & 0.057 & 0.039 \\
\hline Proportion of household dependents & & & -0.032 & 0.026 \\
\hline Numeracy score & & & -0.002 & 0.006 \\
\hline Total years of education and training & & & -0.001 & 0.008 \\
\hline Cognitive function score & & & -0.022 & 0.019 \\
\hline Executive function, z-score & & & 0.038 & $0.018^{* *}$ \\
\hline Completed secondary school & & & 0.008 & 0.046 \\
\hline Weekly cash earnings, 2010 Birr & & & 0.000 & 0.001 \\
\hline Durable assets, z-score & & & -0.011 & 0.020 \\
\hline Wealth index: Production Durables (Z-Score) & & & -0.034 & $0.015^{* *}$ \\
\hline Total debt & & & 0.000 & 0.000 \\
\hline Total savings & & & 0.000 & $0.000^{*}$ \\
\hline Average weekly work hours (over past 2 weeks) : & & & 0.003 & 0.005 \\
\hline Hrs work/wk, cas non-farm labor & & & 0.002 & 0.003 \\
\hline Hrs work/wk, factory & & & -0.003 & 0.004 \\
\hline Hrs work/wk, petty business & & & 0.000 & 0.002 \\
\hline Hrs work/wk, skilled trades & & & -0.002 & 0.004 \\
\hline Hrs work/wk, low skill sal labor & & & -0.002 & 0.002 \\
\hline Hrs work/wk, med skill sal labor & & & 0.000 & 0.000 \\
\hline Hrs work/wk, other work & & & -0.001 & 0.003 \\
\hline Did no work in the past 2 weeks (formal and informal) & & & -0.003 & 0.059 \\
\hline Ever worked in a large firm & & & 0.003 & 0.040 \\
\hline Months experience: Agriculture & & & 0.000 & 0.000 \\
\hline Months experience: Casual work & & & -0.002 & 0.001 \\
\hline Months experience: Factory labor & & & -0.001 & 0.002 \\
\hline Months experience: Petty business & & & -0.000 & 0.001 \\
\hline Months experience: Skilled trade & & & -0.002 & $0.001^{* *}$ \\
\hline Months experience: Wage labor - low skill & & & 0.000 & 0.001 \\
\hline Months experience: Wage labor - medium skill & & & 0.003 & 0.006 \\
\hline Months experience: Other & & & -0.000 & 0.002 \\
\hline Years experience, private firm & & & -0.014 & 0.015 \\
\hline Years experience, workshop & & & -0.115 & 0.085 \\
\hline Years experience working in state/parastatal org & & & 0.021 & 0.035 \\
\hline Years experience working in NGO & & & -0.017 & 0.064 \\
\hline Self perception of health & & & -0.003 & 0.006 \\
\hline Probability of a better job, next month & & & -0.031 & 0.064 \\
\hline Probability of full-time work, next month & & & 0.061 & 0.062 \\
\hline Predicted income uncertainty in next year & & & 0.000 & 0.000 \\
\hline Predicted income uncertainty in next month & & & -0.000 & 0.000 \\
\hline Highest - lowest earnings, past month & & & -0.000 & 0.000 \\
\hline Could borrow 3000 birr & & & 0.060 & $0.033^{*}$ \\
\hline Family relations index, z-score & & & 0.026 & $0.015^{*}$ \\
\hline Friends and nieghbors relations index & & & -0.027 & $0.015^{*}$ \\
\hline Ability to do activities of daily life (0-15) & & & 0.004 & 0.012 \\
\hline Disability: Great difficulty at more than 1 activities & & & 0.225 & 0.191 \\
\hline Change in subjective well being, past yr. & & & -0.008 & 0.013 \\
\hline Symptoms of depression, z-score & & & -0.005 & 0.019 \\
\hline Symptoms of anxiety, z-score & & & 0.012 & 0.020 \\
\hline Risk aversion from IBM games & & & 0.005 & 0.015 \\
\hline Risk aversion score & & & 0.005 & 0.011 \\
\hline Patience score from IBM games & & & -0.007 & 0.017 \\
\hline Time inonsistency score & & & 0.011 & 0.022 \\
\hline Patience index & & & 0.021 & $0.009^{* *}$ \\
\hline Locus of control index & & & -0.006 & 0.015 \\
\hline Self esteem index, s-score & & & 0.019 & 0.016 \\
\hline Self control index & & & -0.016 & 0.014 \\
\hline Agressive or hostile behaviors, z-score & & & 0.014 & 0.014 \\
\hline Conscientiousness index, z-score & & & -0.024 & 0.016 \\
\hline P-value of F-test & 0.1507 & & 0.0022 & \\
\hline$N$ & 947 & & 947 & \\
\hline
\end{tabular}

${ }^{*}$ indicates $p<.1,{ }^{* *}$ indicates $p<.05$, and ${ }^{* * *}$ indicates $p<.01$

Regression estimates use the full sample of baseline respondents with cohort and district fixed effects. 
Appendix Table A.III: Impacts on child outcomes at 5-year endline

\begin{tabular}{|c|c|c|c|c|}
\hline \multirow[b]{2}{*}{ Outcome } & \multirow{2}{*}{$\begin{array}{c}\text { Control } \\
\text { mean } \\
(1)\end{array}$} & \multirow[b]{2}{*}{$\begin{array}{l}\mathrm{N} \\
(2)\end{array}$} & \multicolumn{2}{|c|}{ ITT Estimate } \\
\hline & & & $\begin{array}{c}\text { Job offer } \\
\text { (3) }\end{array}$ & $\begin{array}{l}\text { Start-up } \\
(4)\end{array}$ \\
\hline \multicolumn{5}{|l|}{ Panel A: Fertility outcomes } \\
\hline Number of pregnancies & 0.409 & 1,388 & $\begin{array}{l}-0.024 \\
{[0.039]}\end{array}$ & $\begin{array}{c}0.013 \\
{[0.040]}\end{array}$ \\
\hline Number of children alive & 0.352 & 1,388 & $\begin{array}{l}-0.011 \\
{[0.037]}\end{array}$ & $\begin{array}{l}-0.009 \\
{[0.036]}\end{array}$ \\
\hline Fraction of pregnancies ending in a live birth & 0.856 & 337 & $\begin{array}{c}0.027 \\
{[0.042]}\end{array}$ & $\begin{array}{l}-0.050 \\
{[0.048]}\end{array}$ \\
\hline Franction of pregnancies where the child is still alive & 0.854 & 337 & $\begin{array}{c}0.027 \\
{[0.042]}\end{array}$ & $\begin{array}{c}-0.051 \\
{[0.048]}\end{array}$ \\
\hline \multicolumn{5}{|l|}{ Panel B: Health outcomes } \\
\hline Child age-normalized health index of child & -0.026 & 244 & $\begin{array}{c}0.044 \\
{[0.191]}\end{array}$ & $\begin{array}{c}0.101 \\
{[0.185]}\end{array}$ \\
\hline Age-normalized subjective parent health assessment of child & -0.069 & 309 & $\begin{array}{c}0.171 \\
{[0.123]}\end{array}$ & $\begin{array}{c}0.186 \\
{[0.146]}\end{array}$ \\
\hline Child age-normalized number of times with malaria in past year & -0.146 & 304 & $\begin{array}{l}0.271^{*} \\
{[0.139]}\end{array}$ & $\begin{array}{c}0.452^{* * *} \\
{[0.165]}\end{array}$ \\
\hline Child age-normalized Activities of Daily Life index & -0.055 & 245 & $\begin{array}{c}0.110 \\
{[0.190]}\end{array}$ & $\begin{array}{c}0.199 \\
{[0.187]}\end{array}$ \\
\hline Ability to dress themselves & 0.014 & 265 & $\begin{array}{c}0.065 \\
{[0.180]}\end{array}$ & $\begin{array}{c}0.066 \\
{[0.170]}\end{array}$ \\
\hline Ability to feed themselves & -0.023 & 265 & $\begin{array}{c}0.033 \\
{[0.192]}\end{array}$ & $\begin{array}{c}0.066 \\
{[0.202]}\end{array}$ \\
\hline Ability to use the toilet & 0.017 & 257 & $\begin{array}{l}-0.067 \\
{[0.176]}\end{array}$ & $\begin{array}{l}-0.221 \\
{[0.200]}\end{array}$ \\
\hline Ability to wash themselves & -0.038 & 278 & $\begin{array}{c}0.162 \\
{[0.152]}\end{array}$ & $\begin{array}{c}0.132 \\
{[0.166]}\end{array}$ \\
\hline Aility to bend over & -0.030 & 286 & $\begin{array}{c}0.105 \\
{[0.158]}\end{array}$ & $\begin{array}{c}0.163 \\
{[0.167]}\end{array}$ \\
\hline Ability to say their name & -0.132 & 245 & $\begin{array}{c}0.063 \\
{[0.191]}\end{array}$ & $\begin{array}{c}0.318 \\
{[0.227]}\end{array}$ \\
\hline Ability to walk & -0.027 & 269 & $\begin{array}{c}0.121 \\
{[0.179]}\end{array}$ & $\begin{array}{c}0.233 \\
{[0.181]}\end{array}$ \\
\hline Ability to run & -0.019 & 247 & $\begin{array}{l}-0.004 \\
{[0.181]}\end{array}$ & $\begin{array}{c}0.244 \\
{[0.179]}\end{array}$ \\
\hline \multicolumn{5}{|l|}{ Panel C: Education outcomes } \\
\hline Child age-normalized school and daycare enrollment & -0.051 & 249 & $\begin{array}{c}0.022 \\
{[0.157]}\end{array}$ & $\begin{array}{c}0.449^{* *} \\
{[0.203]}\end{array}$ \\
\hline Child age-normalized educational attainment & -0.000 & 224 & $\begin{array}{c}-0.088 \\
{[0.152]}\end{array}$ & $\begin{array}{l}-0.165 \\
{[0.174]}\end{array}$ \\
\hline
\end{tabular}


Appendix Table A.IV: Instrumental variables approach to the effect of a month's factory work on income

\begin{tabular}{|c|c|c|c|c|}
\hline \multirow{4}{*}{$\begin{array}{l}\text { F-statistics of first stage: } \\
\text { 1-year Endline: } 44 \\
\text { 5-year Endline: } 4 \\
\text { Outcome }\end{array}$} & \multirow{2}{*}{\multicolumn{4}{|c|}{ Months of factory work since baseline }} \\
\hline & & & & \\
\hline & \multicolumn{2}{|c|}{ 1-year Endline } & \multicolumn{2}{|c|}{ 5-year Endline } \\
\hline & $\begin{array}{c}\text { Control mean } \\
\text { (1) }\end{array}$ & $\begin{array}{l}\text { Effect } \\
(2)\end{array}$ & $\begin{array}{c}\text { Control mean } \\
\text { (3) }\end{array}$ & $\begin{array}{l}\text { Effect } \\
(4)\end{array}$ \\
\hline Income and consumption, z-score & -0.00 & $\begin{array}{l}-0.017 \\
(0.037)\end{array}$ & 0.01 & $\begin{array}{l}-0.029 \\
(0.030)\end{array}$ \\
\hline Weekly earnings, 2010 Birr & 34.23 & $\begin{array}{l}-1.767 \\
(2.335)\end{array}$ & 34.97 & $\begin{array}{l}-3.583 \\
(2.846)\end{array}$ \\
\hline Earnings per hour, 2010 Birr & 1.56 & $\begin{array}{l}-0.100 \\
(0.084)\end{array}$ & 1.45 & $\begin{array}{l}-0.140 \\
(0.133)\end{array}$ \\
\hline SD of weekly earnings & 58.15 & $\begin{array}{c}1.851 \\
(3.345)\end{array}$ & 56.52 & $\begin{array}{c}0.337 \\
(2.722)\end{array}$ \\
\hline Household durable consumption assets, z-score & 0.07 & $\begin{array}{l}-0.028 \\
(0.030)\end{array}$ & & \\
\hline Household nondurable consumption, 2010 birr & 665.05 & $\begin{array}{c}18.085 \\
(29.729)\end{array}$ & $1,745.39$ & $\begin{array}{c}-4.375 \\
(35.278)\end{array}$ \\
\hline Household durable productive assets, z-score & -0.12 & $\begin{array}{c}0.018 \\
(0.030)\end{array}$ & & \\
\hline
\end{tabular}

Note: This table shows instrumental variables estimation of the effect of one month in a factory on outcomes of interest. Specifically, we instrument months in factory work since baseline (measured as the sum of months worked in a factory across the 1-year endline, 5-year endline and recall data gathered in the 5-year endline covering the intervening 4 years) with the factory job offer as an instrument for months in factory work. 
Appendix Table A.V: Instrumental variables approach to the effect of a month's factory work on health

\begin{tabular}{|c|c|c|c|c|}
\hline \multirow{4}{*}{$\begin{array}{l}\text { F-statistics of first stage: } \\
\text { 1-year Endline: } 43 \\
\text { 5-year Endline: } 4 \\
\text { Outcome }\end{array}$} & \multirow{2}{*}{\multicolumn{4}{|c|}{ Months of factory work since baseline }} \\
\hline & & & & \\
\hline & \multicolumn{2}{|c|}{ 1-year Endline } & \multicolumn{2}{|c|}{ 5-year Endline } \\
\hline & $\begin{array}{c}\text { Control mean } \\
\text { (1) }\end{array}$ & $\begin{array}{l}\text { Effect } \\
(2)\end{array}$ & $\begin{array}{c}\text { Control mean } \\
\text { (3) }\end{array}$ & $\begin{array}{c}\text { Effect } \\
(4)\end{array}$ \\
\hline Physical health, z-score & 0.06 & $\begin{array}{l}-0.082 \\
(0.035)\end{array}$ & -0.00 & $\begin{array}{c}0.007 \\
(0.024)\end{array}$ \\
\hline Ability to do 5 core activities of daily life $(0-15)$ & 14.07 & $\begin{array}{l}-0.125 \\
(0.069)\end{array}$ & 13.49 & $\begin{array}{l}-0.023 \\
(0.069)\end{array}$ \\
\hline Ability to do 15 activities of daily life $(0-45)$ & & & 39.24 & $\begin{array}{c}0.017 \\
(0.166)\end{array}$ \\
\hline Disability & 0.04 & $\begin{array}{c}0.012 \\
(0.008)\end{array}$ & 0.02 & $\begin{array}{c}0.002 \\
(0.004)\end{array}$ \\
\hline Subjective health assessment $(0-10)$ & 8.91 & $\begin{array}{l}-0.090 \\
(0.061)\end{array}$ & 8.77 & $\begin{array}{c}0.020 \\
(0.040)\end{array}$ \\
\hline Subjective health assessment, 5 years from now (-10 to 10$)$ & 0.76 & $\begin{array}{l}0.009 \\
(0.053)\end{array}$ & 0.10 & $\begin{array}{l}-0.011 \\
(0.033)\end{array}$ \\
\hline General health $(0-60)$ & & & 56.90 & $\begin{array}{c}0.109 \\
(0.144)\end{array}$ \\
\hline Physical sympton count (1-5) & & & 0.21 & $\begin{array}{l}-0.003 \\
(0.013)\end{array}$ \\
\hline Abnormal Spirometry Reading (colour system) & & & 0.02 & $\begin{array}{c}0.007 \\
(0.007)\end{array}$ \\
\hline Mental health and subjective well-being, z-score & -0.11 & $\begin{array}{c}0.018 \\
(0.043)\end{array}$ & 0.00 & $\begin{array}{l}-0.014 \\
(0.030)\end{array}$ \\
\hline Depression symptoms $(0-27)$ & 2.54 & $\begin{array}{l}-0.024 \\
(0.136)\end{array}$ & 2.28 & $\begin{array}{c}0.066 \\
(0.111)\end{array}$ \\
\hline Generalized Anxiety index (0-27) & 2.03 & $\begin{array}{l}0.125 \\
(0.124)\end{array}$ & 1.92 & $\begin{array}{c}0.024 \\
(0.094)\end{array}$ \\
\hline
\end{tabular}

Note: This table shows instrumental variables estimation of the effect of one month in a factory on outcomes of interest. Specifically, we instrument months in factory work since baseline (measured as the sum of months worked in a factory across the 1-year endline, 5-year endline and recall data gathered in the 5-year endline covering the intervening 4 years) with the factory job offer as an instrument for months in factory work. 
Appendix Table A.VI: Breakdown of uses of cash grants among grant recipients (self reported, 1-year follow up)

\begin{tabular}{lc}
\hline & Proportion \\
\hline Business Expenses & $54.7 \%$ \\
Rent & $4.2 \%$ \\
Inputs including equipment & $46.4 \%$ \\
Salaries & $0.9 \%$ \\
Operational costs & $3.3 \%$ \\
& \\
Savings & $34.7 \%$ \\
At home & $13.4 \%$ \\
In the Bank & $21.3 \%$ \\
& \\
Consumption & $7.7 \%$ \\
Food & $1.9 \%$ \\
Clothes & $2.0 \%$ \\
Medical expenses & $0.8 \%$ \\
Other consumption & $3.1 \%$ \\
Transfers to others & \\
\hline
\end{tabular}




\section{Appendix Table A.VII: Effects on occupational choice - detailed categories}

\begin{tabular}{|c|c|c|c|c|c|c|c|c|c|}
\hline \multirow[b]{3}{*}{ Outcome } & \multicolumn{3}{|c|}{ 1-year Endline } & \multicolumn{3}{|c|}{ 5-year Endline } & \multirow{2}{*}{\multicolumn{2}{|c|}{$\begin{array}{l}\text { Cross-year difference } \\
\text { p-value }\end{array}$}} & \multirow{3}{*}{$\begin{array}{c}5 \text {-year } \\
\text { Av. earnings } \\
\text { Control } \\
(9)\end{array}$} \\
\hline & \multirow{2}{*}{$\begin{array}{c}\text { Control } \\
\text { mean } \\
(1)\end{array}$} & \multicolumn{2}{|c|}{ ITT Estimate } & \multirow{2}{*}{$\begin{array}{c}\text { Control } \\
\text { mean } \\
(4)\end{array}$} & \multicolumn{2}{|c|}{ ITT Estimate } & & & \\
\hline & & $\begin{array}{l}\text { Job } \\
(2)\end{array}$ & $\begin{array}{c}\text { Grant } \\
(3)\end{array}$ & & $\begin{array}{l}\text { Job } \\
(5)\end{array}$ & $\begin{array}{c}\text { Grant } \\
(6)\end{array}$ & $\begin{array}{l}\text { Job } \\
(7)\end{array}$ & $\begin{array}{c}\text { Grant } \\
(8)\end{array}$ & \\
\hline Farm own land & 0.077 & $\begin{array}{l}0.028^{*} \\
{[0.017]}\end{array}$ & $\begin{array}{c}0.049 * * * \\
{[0.018]}\end{array}$ & 0.016 & $\begin{array}{l}-0.002 \\
{[0.010]}\end{array}$ & $\begin{array}{c}0.011 \\
{[0.011]}\end{array}$ & 0.111 & 0.054 & $\begin{array}{c}3.95 \\
(11.17)\end{array}$ \\
\hline Casual labor & 0.108 & $\begin{array}{l}-0.019 \\
{[0.020]}\end{array}$ & $\begin{array}{c}0.027 \\
{[0.023]}\end{array}$ & 0.049 & $\begin{array}{c}0.012 \\
{[0.016]}\end{array}$ & $\begin{array}{l}0.031^{*} \\
{[0.017]}\end{array}$ & 0.195 & 0.894 & $\begin{array}{c}37.41 \\
(109.29)\end{array}$ \\
\hline Animal rearing & 0.032 & $\begin{array}{l}-0.009 \\
{[0.011]}\end{array}$ & $\begin{array}{c}0.130 * * * \\
{[0.020]}\end{array}$ & 0.012 & $\begin{array}{l}-0.007 \\
{[0.006]}\end{array}$ & $\begin{array}{l}-0.002 \\
{[0.006]}\end{array}$ & 0.821 & 0.000 & $\begin{array}{c}36.87 \\
(53.19)\end{array}$ \\
\hline Farm wage labor & 0.140 & $\begin{array}{c}0.043^{* *} \\
{[0.020]}\end{array}$ & $\begin{array}{c}-0.062^{* * *} \\
{[0.021]}\end{array}$ & 0.012 & $\begin{array}{c}0.039^{* *} \\
{[0.016]}\end{array}$ & $\begin{array}{c}0.006 \\
{[0.009]}\end{array}$ & 0.844 & 0.002 & $\begin{array}{c}9.83 \\
(24.08)\end{array}$ \\
\hline Food and drinks sales & 0.052 & $\begin{array}{c}-0.033^{* *} \\
{[0.013]}\end{array}$ & $\begin{array}{c}0.113^{* * *} \\
{[0.022]}\end{array}$ & 0.051 & $\begin{array}{c}0.005 \\
{[0.019]}\end{array}$ & $\begin{array}{c}0.018 \\
{[0.019]}\end{array}$ & 0.086 & 0.000 & $\begin{array}{c}92.93 \\
(121.19)\end{array}$ \\
\hline Shop-keeping & 0.060 & $\begin{array}{l}-0.022 \\
{[0.015]}\end{array}$ & $\begin{array}{c}0.011 \\
{[0.018]}\end{array}$ & 0.057 & $\begin{array}{l}-0.024 \\
{[0.016]}\end{array}$ & $\begin{array}{c}0.007 \\
{[0.018]}\end{array}$ & 0.923 & 0.893 & $\begin{array}{c}80.16 \\
(136.61)\end{array}$ \\
\hline Trade & 0.073 & $\begin{array}{c}-0.031^{*} \\
{[0.016]}\end{array}$ & $\begin{array}{c}0.161^{* * *} \\
{[0.025]}\end{array}$ & 0.061 & $\begin{array}{l}-0.019 \\
{[0.018]}\end{array}$ & $\begin{array}{c}0.040^{* *} \\
{[0.019]}\end{array}$ & 0.581 & 0.000 & $\begin{array}{c}46.24 \\
(86.34)\end{array}$ \\
\hline Vocational & 0.043 & $\begin{array}{l}-0.018 \\
{[0.011]}\end{array}$ & $\begin{array}{l}-0.018 \\
{[0.012]}\end{array}$ & 0.071 & $\begin{array}{c}-0.038^{* * *} \\
{[0.015]}\end{array}$ & $\begin{array}{c}-0.037^{* *} \\
{[0.015]}\end{array}$ & 0.238 & 0.300 & $\begin{array}{c}75.34 \\
(131.55)\end{array}$ \\
\hline Tailor or weavers & 0.018 & $\begin{array}{l}-0.012 \\
{[0.007]}\end{array}$ & $\begin{array}{l}-0.013 \\
{[0.008]}\end{array}$ & 0.030 & $\begin{array}{c}-0.019 * * \\
{[0.009]}\end{array}$ & $\begin{array}{l}-0.007 \\
{[0.010]}\end{array}$ & 0.421 & 0.639 & $\begin{array}{c}59.41 \\
(108.55)\end{array}$ \\
\hline Crafts & 0.017 & $\begin{array}{c}0.009 \\
{[0.009]}\end{array}$ & $\begin{array}{c}0.009 \\
{[0.009]}\end{array}$ & 0.014 & $\begin{array}{c}0.014 \\
{[0.017]}\end{array}$ & $\begin{array}{l}-0.002 \\
{[0.006]}\end{array}$ & 0.801 & 0.277 & $\begin{array}{c}16.25 \\
(27.86)\end{array}$ \\
\hline Factory & 0.233 & $\begin{array}{c}0.260^{* * *} \\
{[0.031]}\end{array}$ & $\begin{array}{c}-0.134^{* * *} \\
{[0.027]}\end{array}$ & 0.159 & $\begin{array}{c}0.036 \\
{[0.033]}\end{array}$ & $\begin{array}{c}-0.071^{* *} \\
{[0.028]}\end{array}$ & 0.000 & 0.071 & $\begin{array}{c}33.92 \\
(96.35)\end{array}$ \\
\hline Driver & 0.008 & $\begin{array}{c}-0.006^{*} \\
{[0.003]}\end{array}$ & $\begin{array}{c}0.009 \\
{[0.007]}\end{array}$ & 0.033 & $\begin{array}{l}-0.021^{*} \\
{[0.012]}\end{array}$ & $\begin{array}{c}0.002 \\
{[0.015]}\end{array}$ & 0.194 & 0.660 & $\begin{array}{c}88.23 \\
(159.30)\end{array}$ \\
\hline Secretary & 0.012 & $\begin{array}{c}0.002 \\
{[0.007]}\end{array}$ & $\begin{array}{l}-0.007 \\
{[0.006]}\end{array}$ & 0.018 & $\begin{array}{c}0.000 \\
{[0.008]}\end{array}$ & $\begin{array}{c}0.004 \\
{[0.010]}\end{array}$ & 0.868 & 0.364 & $\begin{array}{c}0.94 \\
(2.81)\end{array}$ \\
\hline Domestic & 0.093 & $\begin{array}{c}-0.047^{* *} \\
{[0.019]}\end{array}$ & $\begin{array}{c}-0.038^{* *} \\
{[0.019]}\end{array}$ & 0.055 & $\begin{array}{c}0.008 \\
{[0.017]}\end{array}$ & $\begin{array}{c}0.003 \\
{[0.017]}\end{array}$ & 0.021 & 0.087 & $\begin{array}{l}13.75 \\
(30.58)\end{array}$ \\
\hline Clerical & 0.033 & $\begin{array}{l}-0.018 \\
{[0.011]}\end{array}$ & $\begin{array}{l}0.029^{*} \\
{[0.016]}\end{array}$ & 0.051 & $\begin{array}{c}0.028 \\
{[0.019]}\end{array}$ & $\begin{array}{c}0.055^{* * *} \\
{[0.021]}\end{array}$ & 0.022 & 0.226 & $\begin{array}{c}35.89 \\
(79.87)\end{array}$ \\
\hline Waiter & 0.052 & $\begin{array}{l}-0.016 \\
{[0.015]}\end{array}$ & $\begin{array}{c}-0.029^{* *} \\
{[0.014]}\end{array}$ & 0.035 & $\begin{array}{l}-0.016 \\
{[0.014]}\end{array}$ & $\begin{array}{l}-0.004 \\
{[0.014]}\end{array}$ & 0.991 & 0.189 & $\begin{array}{l}18.96 \\
(35.21)\end{array}$ \\
\hline Other & 0.090 & $\begin{array}{c}0.001 \\
{[0.018]}\end{array}$ & $\begin{array}{c}0.016 \\
{[0.020]}\end{array}$ & 0.085 & $\begin{array}{l}-0.012 \\
{[0.021]}\end{array}$ & $\begin{array}{l}-0.021 \\
{[0.017]}\end{array}$ & 0.606 & 0.124 & $\begin{array}{c}38.26 \\
(84.97)\end{array}$ \\
\hline
\end{tabular}

${ }^{*}$ indicates $p<.1,{ }^{* *}$ indicates $p<.05$, and ${ }^{* * *}$ indicates $p<.01$

Dependent variables are dummy varaibles equal to 1 if the respondent has working in the respective occupation in the last year. Regression estimates use the full sample of baseline respondents with cohort and district fixed effects. We dropped four occupation categories that comprised less than 1 percent of all work, namely: soldiering, public works, teaching and mining. 
Appendix Table A.VIII: Effects on household assets at 1-year endline

\begin{tabular}{|c|c|c|c|c|}
\hline \multirow[b]{2}{*}{ Outcome } & \multirow{2}{*}{$\begin{array}{c}\text { Control } \\
\text { mean } \\
(1)\end{array}$} & \multirow[b]{2}{*}{$\begin{array}{l}\mathrm{N} \\
(2)\end{array}$} & \multicolumn{2}{|c|}{ ITT Estimate } \\
\hline & & & $\begin{array}{c}\text { Job offer } \\
\text { (3) }\end{array}$ & $\begin{array}{c}\text { Start-up } \\
(4)\end{array}$ \\
\hline Has access to land that is being cultivated & 0.094 & 816 & $\begin{array}{c}0.040 \\
{[0.025]}\end{array}$ & $\begin{array}{c}0.024 \\
{[0.026]}\end{array}$ \\
\hline Has access to land for business use & 0.037 & 817 & $\begin{array}{c}0.030 \\
{[0.018]}\end{array}$ & $\begin{array}{c}0.049^{* *} \\
{[0.021]}\end{array}$ \\
\hline Has access to land that is rented out & 0.040 & 816 & $\begin{array}{c}0.001 \\
{[0.018]}\end{array}$ & $\begin{array}{c}0.022 \\
{[0.021]}\end{array}$ \\
\hline Sewing or weaving equipment & 0.030 & 827 & $\begin{array}{l}-0.021 \\
{[0.014]}\end{array}$ & $\begin{array}{c}0.012 \\
{[0.021]}\end{array}$ \\
\hline Cattle & 0.558 & 825 & $\begin{array}{l}-0.092 \\
{[0.119]}\end{array}$ & $\begin{array}{l}0.265^{*} \\
{[0.136]}\end{array}$ \\
\hline Goats and sheep & 0.248 & 826 & $\begin{array}{c}0.040 \\
{[0.097]}\end{array}$ & $\begin{array}{c}0.472^{* * *} \\
{[0.130]}\end{array}$ \\
\hline Poultry and Birds & 0.661 & 827 & $\begin{array}{c}0.057 \\
{[0.195]}\end{array}$ & $\begin{array}{c}0.977^{* * *} \\
{[0.289]}\end{array}$ \\
\hline Stove & 0.155 & 827 & $\begin{array}{l}-0.001 \\
{[0.029]}\end{array}$ & $\begin{array}{l}-0.031 \\
{[0.030]}\end{array}$ \\
\hline Electric mitad & 0.296 & 826 & $\begin{array}{l}-0.022 \\
{[0.034]}\end{array}$ & $\begin{array}{c}0.006 \\
{[0.037]}\end{array}$ \\
\hline Motor Vehicle (car or truck) & 0.013 & 827 & $\begin{array}{l}-0.006 \\
{[0.009]}\end{array}$ & $\begin{array}{l}-0.010 \\
{[0.006]}\end{array}$ \\
\hline Motorcycles & 0.000 & 827 & $\begin{array}{c}0.002 \\
{[0.002]}\end{array}$ & $\begin{array}{l}-0.001 \\
{[0.002]}\end{array}$ \\
\hline Bajaj & 0.003 & 827 & $\begin{array}{l}-0.001 \\
{[0.004]}\end{array}$ & $\begin{array}{l}-0.000 \\
{[0.006]}\end{array}$ \\
\hline Refrigerator & 0.089 & 826 & $\begin{array}{c}0.031 \\
{[0.023]}\end{array}$ & $\begin{array}{c}0.013 \\
{[0.024]}\end{array}$ \\
\hline
\end{tabular}

${ }^{*}$ indicates $p<.1{ }^{* *}$ indicates $p<.05$, and ${ }^{* * *}$ indicates $p<.01$ 
Appendix Figure A.I: Progression of employment across time: factory job group

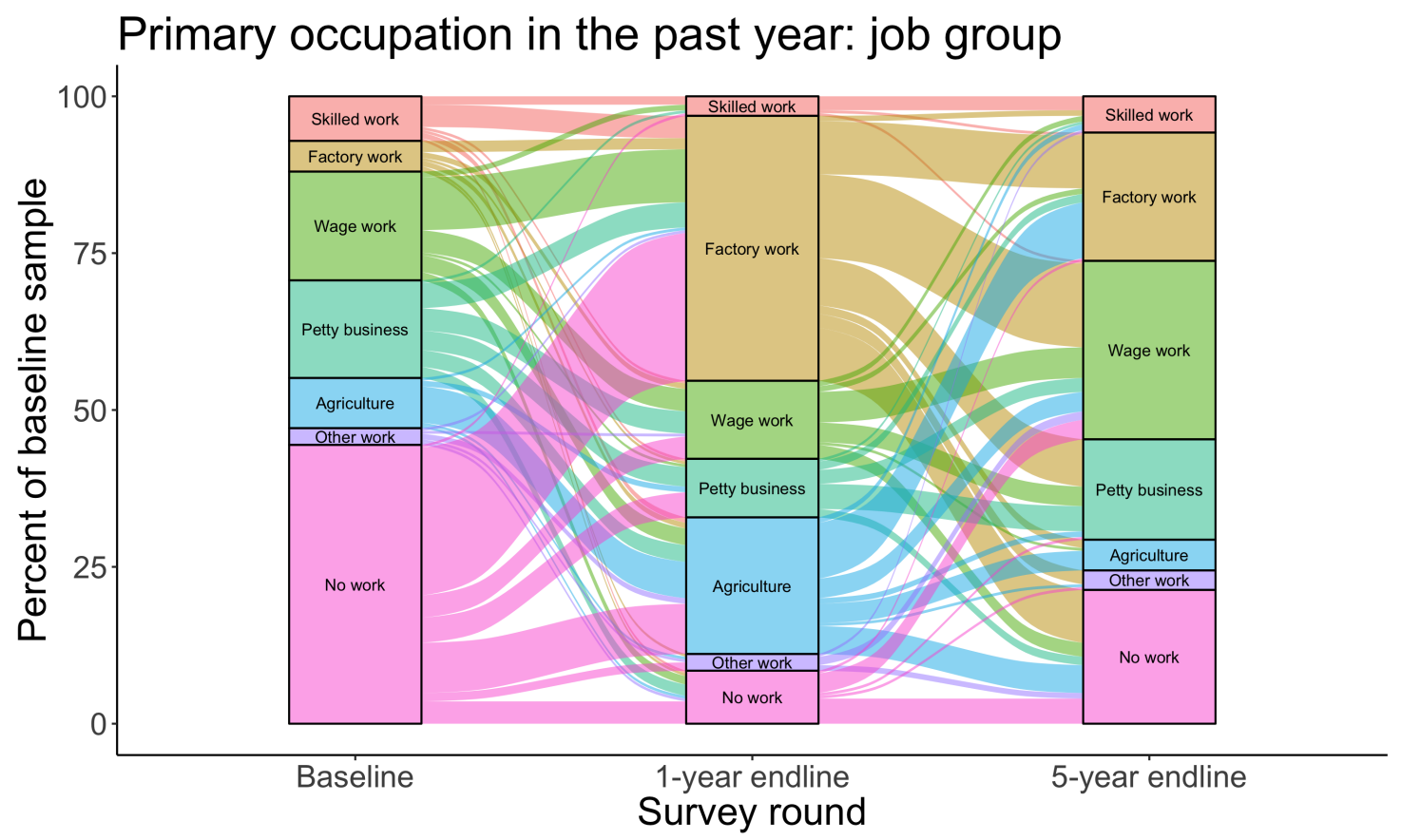

Appendix Figure A.II: Progression of employment across time: start-up grant group

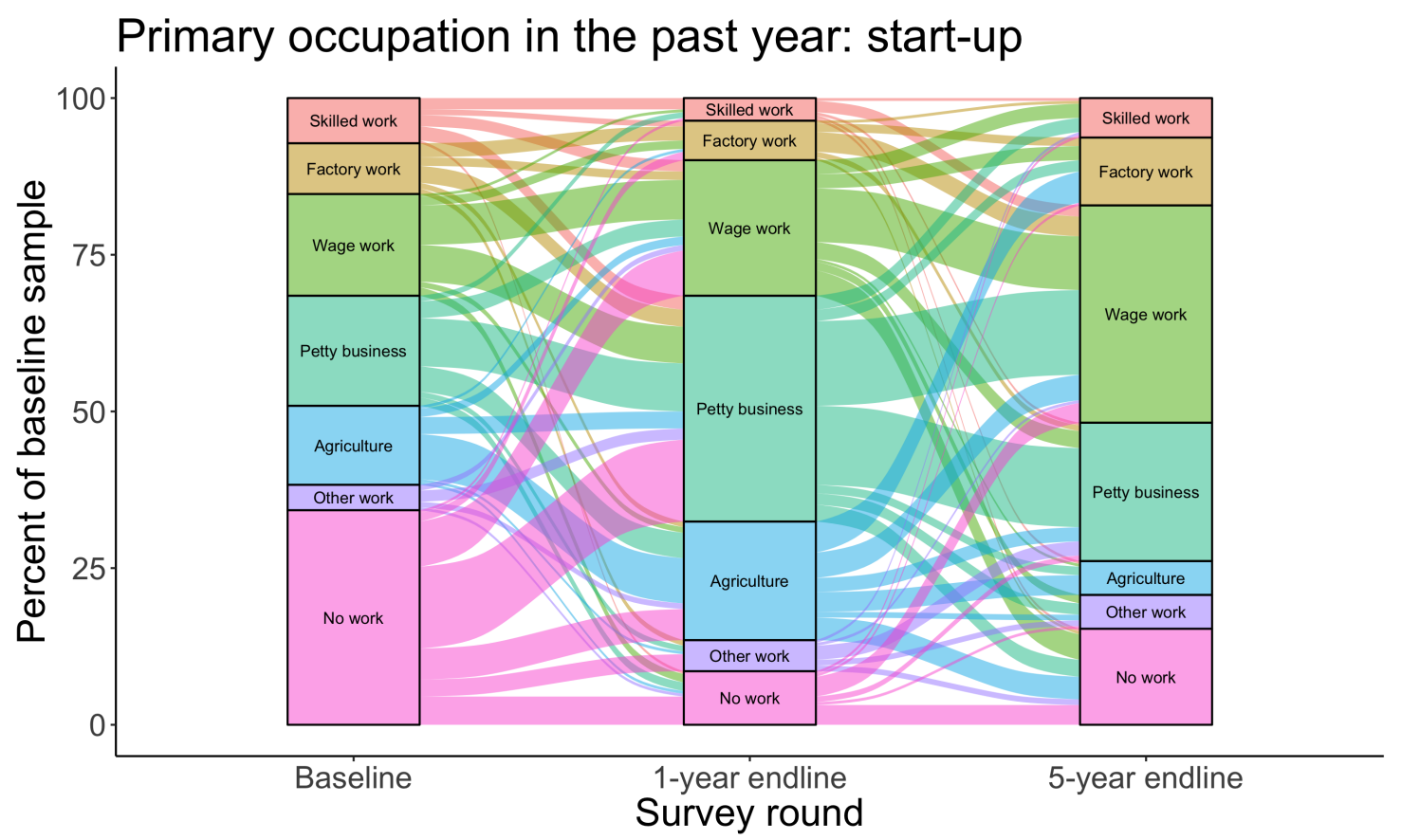


Appendix Figure A.III: Progression of employment across time: control group

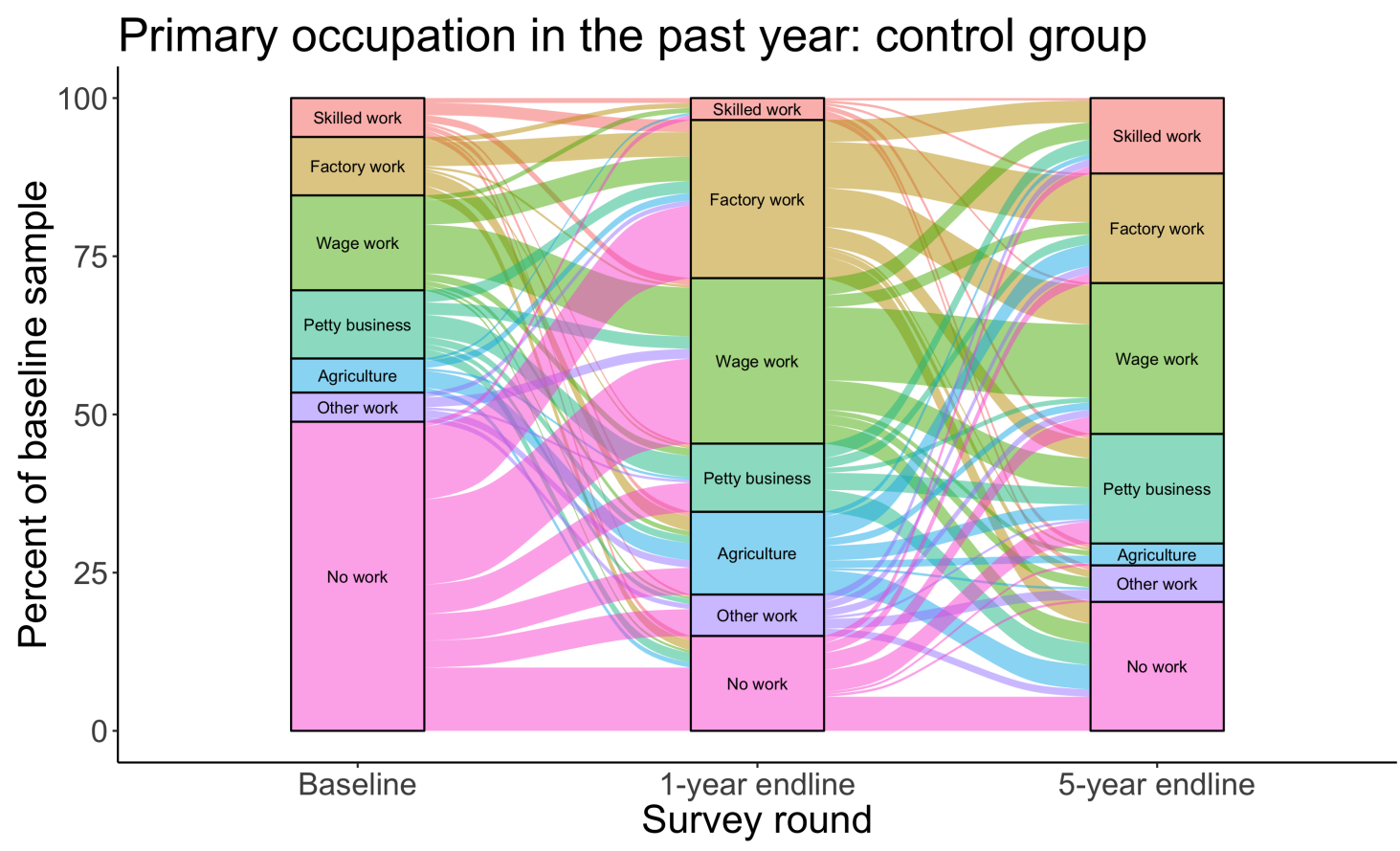

Appendix Figure A.IV: Net present value of intervention according to treatment effects on income with imputed year-1 earnings included.

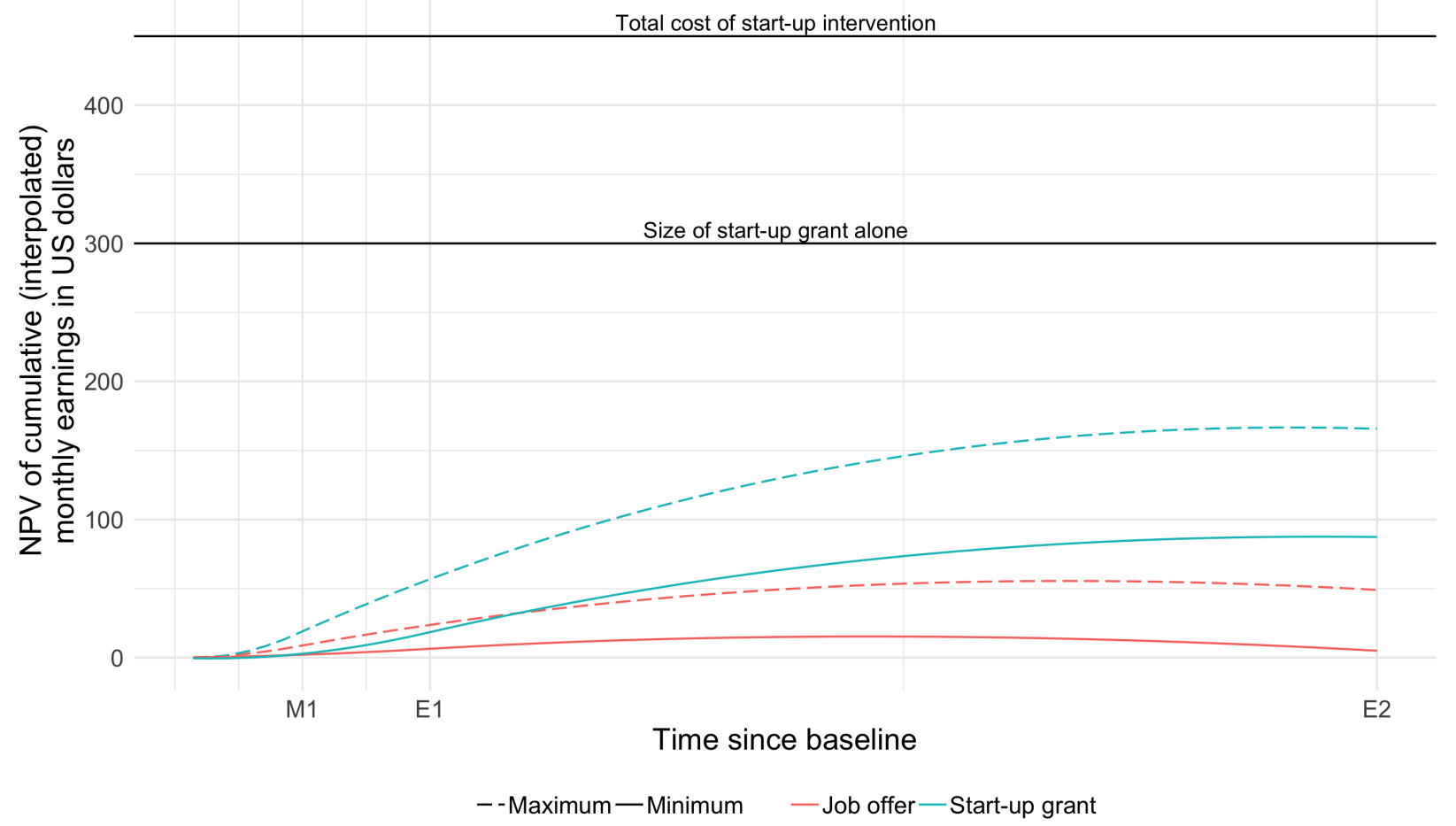

